\title{
Vascular targets of redox signalling in diabetes mellitus
}

\author{
M. M.Spitaler, W.F. Graier \\ Department of Medical Biochemistry and Medical Molecular Biology, Karl-Franzens University of Graz, Graz, Austria
}

\begin{abstract}
There is overwhelming evidence for an involvement of reactive oxygen species (ROS) in the pathogenesis of diabetes-associated vascular complications. However, neither the exact source of the ROS initiating cascades leading to cell dysfunction in diabetes nor their chemical nature is fully understood. Furthermore, despite our knowledge of the crucial role of ROS in diabetes, little is known about the actual targets and the molecular consequences of the interaction of ROS with cellular signalling pathways.

Therefore, we aim to provide an overview of ROS (i.e. $\mathrm{O}_{2}{ }^{-}-, \mathrm{NO}^{\bullet}, \mathrm{ONOO}^{-}$and $\mathrm{H}_{2} \mathrm{O}_{2}$ ) and their vascular sources in diabetes and to summarise recent knowledge on the mechanisms underlying increased ROS production within the vascular wall. In addition, possible targets of diabetes and ROS within the vas-
\end{abstract}

culature are discussed. These include, the effects of ROS on small guanine nucleotide binding proteins, the cytoskeleton, protein kinases (e.g. tyrosine kinases), metalloproteinases, ion homeostasis and transcriptional regulation.

Such analysis makes it clear that the generation of ROS could affect a large number of various signalling pathways and proteins. Thus, a better knowledge of the functional diversity and pathological consequences of each individual pathway activated by ROS is essential to understand the mechanisms of diabetesassociated vascular complications. [Diabetologia (2002) 45:476-494]

Keywords Diabetes, reactive oxygen species, superoxide, nitric oxide, RhoA, Rac, tyrosine kinases, serine/threonine kinases, $\mathrm{Ca}^{2+}$-homeostasis, NF- $x \mathrm{~B}$, NFAT, AP-1, matrix metalloproteinases.
Received: 29 August 2001 and in revised form:17 December 2001

Corresponding author: W.F. Graier, Department of Medical Biochemistry and Medical Molecular Biology, Karl-Franzens University of Graz, Harrachgasse 21/III, Graz, Austria, e-mail: wolfgang.graier@kfunigraz.ac.at

Abbreviations: AA, Arachidonic acid; AGE, advanced glycation end product; AngII, angiotensin II; AP-1, activator protein-1; ATF-1/2, Activated transcription factor-1/2; $\mathrm{BH}_{4}$, tetrahydrobiopterin; BHA, 2(3)-t- Butyl-4-hydroxyanisole; BMK1, big MAPK; t-BuOOH, tertiary Butylhydroperoxide; Cas, crkassociated substrate; $C D C 42$, homologous to yeast cell division cycle gene 42; CHOP, C/EBP homologous protein (stress activated transcription factor); $\mathrm{COX}$, cyclooxygenase; CREB, cAMP-responsive element binding protein; Crk p130, CT-10 regulated kinase; CYP450, cytochrome P450 monooxygenase; DPI, diphenylene iodonium; EC, endothelial cell; EDHF, endothelial derived hyperpolarising factor; ERK 1/2, extracellular signal-regulated kinase 1/2; FAK, focal adhesion kinase; $\mathrm{H}_{2} \mathrm{O}_{2}$, hydrogen peroxide; HMG, hydroxymethylglutaryl; HX, hypoxanthine; $\mathrm{IP}_{3}(\mathrm{R})$, Inositol- 1, 4, 5- triphosphate (receptor); JNK, cJun N-terminal kinase; LDL, low density lipoprotein;
L-NNA, L-nitroarginine; LO`, lipid alkoxyl radical; LOO`, lipid peroxyl radical; MAPK, mitogen-activated protein kinase; MAPKK, mitogen-activated protein kinase kinase; MAPKKK, mitogen-activated protein kinase kinase kinase; MEF2 (RSRF), myocyte enhancer factor2 (serum response factor-related proteins); MMP, matrix metalloproteinase; MPO, myeloperoxidase; NAC, N-acetyl-L-cysteine; NF-AT, nuclear factor of activated T cells; $N F-\varkappa \mathrm{B}$, nuclear factor- $\varkappa \mathrm{B}$; NGA, nordihydroguaiaretic acid; $\mathrm{NHE}, \mathrm{Na}^{+} / \mathrm{H}^{+}$exchanger; NOS, NO synthase; eNOS, endothelial NOS; NAD(P)H, oxidase; $\mathrm{O}_{2}{ }^{-}$, superoxide anions; $\mathrm{ONOO}^{-}$, peroxynitrite; Phox, phagocytic oxidase; PI3-kinase, phosphatidylinositol 3 kinase; $\mathrm{PKB}$, protein kinase $\mathrm{B}$ (Akt); pS, picosiemens; Rac, ras-related $\mathrm{C}_{3}$-botulinum toxin substrate; Ras, rat sarcoma virus; Rho, ras homologous; ROS, reactive oxygen species; p90RSK, $90 \mathrm{kDa}$ ribosomal S6 kinases; = MAPKAP-K1, MAPK-activated protein kinase-1; RyR, ryanodine receptor; SAPK, stress-activated protein kinase; SERCA, $\mathrm{Ca}^{2+} \mathrm{ATP}$-ase; SMC, smooth muscle cell; SOD, superoxide dismutase; TCF (Elk-1), ternary complex factor; TK, tyrosine kinase; TNF, tumour necrosis factor; TPA, 12-O- tetradecanoylphorbol-13-acetate; TRE, TPA responsive element; TRP, transient receptor potential; X, xanthine; XOX, xanthine oxidase 
Cardiovascular complications are the leading cause of morbidity and mortality in patients with diabetes mellitus. Because the onset and progression of associated complications are delayed in patients with good glycaemic control, hyperglycaemia appears an important regulator of vascular lesion development. Diabetes and hyperglycaemia are strongly associated with endothelial dysfunction, which is an early hallmark in the development of atherosclerosis. The term endothelial dysfunction has been used for several pathological conditions, including altered anticoagulant and anti-inflammatory properties of the endothelium, impaired modulation of vascular growth, dysregulation of vascular remodelling and impaired endothelium-dependent vasorelaxation caused by the loss of nitric oxide ( $\mathrm{NO}^{\bullet}$ ) bioactivity in the vessel wall.

Furthermore, alteration of platelet function contributes to microthrombus formation and could play an important role in the pathogenesis of diabetic micro and macroangiopathies. Hyperglycaemia potentiates platelet aggregation, and its subsequent release of platelet-derived growth factor, $\mathrm{AB}$, inhibits protein tyrosine phosphatase (PTP) activity and increases phosphorylation of tyrosine kinases in platelets exposed to collagen. Inhibition of the respiratory chain or application of SOD-mimetic prevents these effects, indicating that mitochondrial superoxide generation could play an important role in platelet dysfunction observed in patients suffering from diabetes [1].

Recent studies indicate that higher D-glucose concentrations change several intracellular signal transduction cascades in the vascular wall, including modulation of protein kinase $\mathrm{C}$ (PKC) (for review see [2]), activation of mitogen-activated protein kinases and the generation of reactive oxygen species (ROS). Furthermore, hyperglycaemia-induced oxidative stress might be the cause as well as the result of the accumulation of advanced glycation end products (AGEs) or both [3] that have been demonstrated to enhance the expression of vascular cell adhesion molecule- 1 and oxidative stress upon interaction with specific receptors [4].

While the ultimate effects of diabetes and hyperglycaemia on blood vessel function is well documented, the underlying mechanisms leading to dysfunctions are not clear. During the last few years, convincing evidence indicates that the generation of ROS plays a crucial role in the development and the progression of vascular dysfunction associated with a variety of diseases, such as hypercholesterolaemia $[5,6,7]$, hypertension $[8,9]$ and diabetes mellitus $[1,8,10,11]$. Under these conditions an excessive endogenous formation of ROS apparently overcomes cellular antioxidant defence mechanisms, resulting in ROS-initiated modification of lipids, proteins, carbohydrates and DNA [12]. This condition is commonly termed oxida- tive stress. In addition to the oxidative modification of target molecules affecting their function, distribution or metabolism, ROS, such as superoxide anions $\left(\mathrm{O}_{2}{ }^{-}\right)$or nitric oxide $\left(\mathrm{NO}^{\bullet}\right)$ also affect or initiate signal cascades directly. Remarkably, $\mathrm{O}_{2}{ }^{-}-$seems to function as a messenger in signal transduction that mediates downstream signalling (e.g. Ras and Rac) even under physiological conditions [13]. Although in mammalian cells there is no proof for proteins capable of sensing $\mathrm{O}_{2}{ }^{-}-$or $\mathrm{H}_{2} \mathrm{O}_{2}$, growing evidence supports the concept that $\mathrm{O}_{2}{ }^{-}-$and probably other oxidants serve as physiological signal molecules at lower concentrations, while larger amounts of the same ROS induce cell damage and dysfunction [14].

Thus, the production and action of ROS represent crucial phenomena involved in physiological and pathological mechanisms. This review aims to provide an overview of ROS-sensitive signalling proteins and pathways that forward a signal to alter cell function and gene expression. This review describes proteins and signal cascades that contribute to the development of diabetes-associated vascular dysfunction and blood vessel complications, but does not claim completeness.

\section{Chemistry of ROS}

The term ROS describes a group of small, reactive oxygen-containing molecules that are either free radicals containing oxygen or nitrogen-based unpaired electrons or compounds that are not free radicals themselves, but have oxidising properties that contribute to oxidant stress (Fig.1).

Among the free radicals, superoxide anions $\left(\mathrm{O}_{2}^{\circ}-\right)$, hydroxyl radical $\left(\mathrm{HO}^{\circ}\right)$, nitric oxide $\left(\mathrm{NO}^{\circ}\right)$ and lipid radicals $\left(\mathrm{LO}^{\bullet}, \mathrm{LOO}^{\circ}\right)$ are the most prominent. Remarkably, not all of these oxygen-containing radicals have high oxidative potential and reactivity to interact with cellular molecules such as proteins or lipids. Thus, the half-life of these radicals in vivo varies from few milliseconds (e.g. $\mathrm{HO}^{\circ}$ ) up to several seconds and even minutes (e.g. $\mathrm{O}_{2}{ }^{\circ}, \mathrm{LOO}^{\circ}$ ). Nonradical ROS, such as hydrogen peroxide $\left(\mathrm{H}_{2} \mathrm{O}_{2}\right)$, hypochloric acid $(\mathrm{HOCl})$ and peroxynitrite $\left(\mathrm{ONOO}^{-}\right)$, are compounds that emerge under oxidative stress and mediate oxidative signalling to their environment. $\mathrm{ONOO}^{-}$is formed by the ultrafast reaction of $\mathrm{O}_{2}{ }^{\circ-}$ with $\mathrm{NO}^{\bullet}$, while $\mathrm{HOCl}$ and $\mathrm{H}_{2} \mathrm{O}_{2}$ are products of the myeloperoxidase (MPO) and superoxide dismutase (SOD), respectively. $\mathrm{O}_{2}{ }^{-}-$are probably not the only radicals that react with $\mathrm{NO}^{\circ}$. Lipid radicals $\left(\mathrm{LO}^{\bullet}\right.$ and $\mathrm{LOO}^{\circ}$ ) can react with $\mathrm{NO}^{\circ}$ to form $\mathrm{LONO}$ and LOONO [15]. Recently it has been shown that even a reaction between $\mathrm{HO}^{\bullet}$ and $\mathrm{NO}^{\bullet}$ is possible [16].

It is obvious that ROS differ considerably in terms of the effects they mediate in intact cells. Thus, in or- 


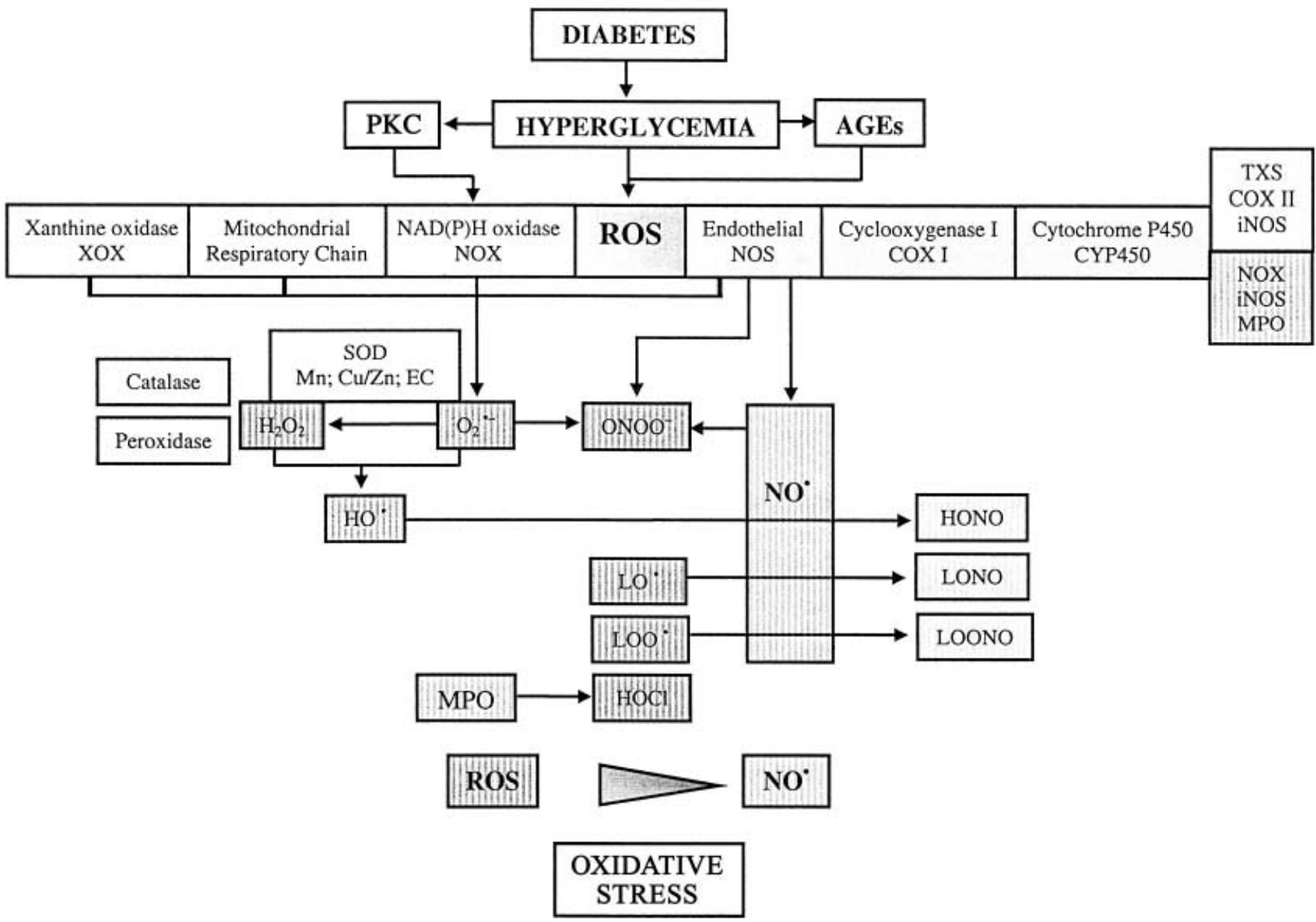

\begin{tabular}{|c|c|c|c|c|}
\hline $\begin{array}{c}\text { Constitutively } \\
\text { ROS producing }\end{array}$ & $\begin{array}{c}\text { Inducible } \\
\text { ROS producing }\end{array}$ & $\begin{array}{c}\text { Invading } \\
\text { ROS producioxidative } \\
\text { Enzymes }\end{array}$ & $\begin{array}{c}\text { By- } \\
\text { product }\end{array}$ \\
\hline
\end{tabular}

Fig. 1. Major ROS and their sources involved in diabetics processes

der to assess the effect of ROS on the vasculature, each individual reactive oxygen molecule needs to be performed separately.

\section{ROS in the vascular wall}

Several sources of ROS (Fig. 1) contribute to the development of circulatory complications and vascular dysfunction. Enzymes responsible for ROS formation in the vascular wall can be divided into three groups: enzymes that are (i) constitutively active in the vascular wall, (ii) that are induced in vascular cells under pathological conditions, and (iii) ROS producing enzymes that are imported into the vascular wall by invading cells. Members of the first group are cyclooxygenase (COX I), lipooxygenase [17], cy- tochrome P450 (CYP450), xanthine oxidase (XO), NAD $(\mathrm{P}) \mathrm{H}$ oxidase, superoxide dismutase (SOD), the endothelial nitric oxide synthase (eNOS) and the enzyme complexes contributing to the mitochondrial respiratory chain. While the expression of these constitutive enzymes is enhanced in various diseases, the expression of inducible enzymes, such as thromboxane synthase (TXS), cyclooxygenase 2 (COX II) and inducible nitric oxide synthase (iNOS) is switched on under pathological conditions. Monocyte NADH/NADPH oxidase, monocyte and macrophage iNOS (iNOS) and myeloperoxidase (MPO) [18] belong to the group of ROS-producing enzymes that are imported by invasion of blood cells into the vascular wall.

$\mathrm{O}_{2}{ }^{-}-$and $\mathrm{H}_{2} \mathrm{O}_{2}$ can interact with each other or with iron or copper containing molecules (Fentonor Haber-Weiss- reaction) to generate the highly reactive $\mathrm{HO}^{\circ}$. In addition to enzymatically produced ROS, the cellular production of one ROS can lead to the production of several others through radical chain reactions. The reaction between radicals and 
polyunsaturated fatty acids within cell membranes results in a fatty acid peroxyl radical ( $\left.\mathrm{R}-\mathrm{COO}^{\circ}\right)$ that, in turn, attacks adjacent fatty acid side chains to produce other lipid radicals. These accumulate in the cell membrane and can have multiple effects on cellular function, including plasma membrane leakage and dysfunction of membrane bound receptors [8]. Finally, the generation of ROS also occurs as a result of non-enzymatic processes that involve the autoxidation of D-glucose in the presence of transition ions such as $\mathrm{Fe}^{2+}$ or $\mathrm{Cu}^{+}[19,20]$. Notably, transition ions that could serve as a source of metal-catalysed ROS can be sequestered by glycated proteins [21,22].

There are five enzymes or enzyme-complexes that are frequently discussed to contribute to diabetes-associated ROS generation within the vascular wall (Fig. 1).

$N A D(P) H$ oxidase. Several isoforms of this multienzyme complex have been found in the vascular wall [9]. In general, enzyme activity is provided by the cytochrome $b_{558}$, an integral membrane protein composed of the gp91phox and p22phox subunits. The activity of $b_{558}$ is dependent upon its interaction with the additional components p67phox, p47phox, p40phox and the small $\mathrm{G}$ protein, ras-related $\mathrm{C}_{3}$-botulinum toxin substrate (Rac) [14, 23]. The two isoforms of Rac, Rac1 and Rac2 [24, 25], promote the assembly of the NAD $(\mathrm{P}) \mathrm{H}$ oxidase $[25,26]$ as well as the stability of this multicomplex enzyme $[25,26]$. While Rac2, which has a higher affinity for the NAD(P)H oxidase than Rac1 [14], seems to be constitutively associated with membranes, Rac1 translocates from the cytosol to the membrane together with the other components upon stimulation of the respiratory burst. Subsequently, in experimental hyperglycaemia, the production of $\mathrm{O}_{2}{ }^{-}-$by endothelial and smooth muscle NAD $(\mathrm{P}) \mathrm{H}$ oxidase has been discussed $[27,28,29]$. In line with the potential role of NAD $(\mathrm{P}) \mathrm{H}$ oxidase in the diabetic vessel, NADH-dependent generation of $\mathrm{O}_{2}{ }^{-}-$was described in endothelium and vascular smooth muscle cells $[30,31,32$, 33]. In segments of human saphenous veins obtained from patients undergoing routine coronary artery bypass surgery [34] and in uterine arteries from diabetic patients increased $\mathrm{NAD}(\mathrm{P}) \mathrm{H}$ oxidase-dependent $\mathrm{O}_{2}{ }^{-}-$production occurs. In agreement with these findings, Inoguchi and co-workers reported the PKC-mediated formation of $\mathrm{O}_{2}{ }^{-}-$in cultured vascular cells under hyperglycaemic conditions which was sensitive to diphenylene iodonium (DPI), an inhibitor of flavoproteins (e.g. NAD(P)H oxidase, eNOS) [29]. The involvement of PKC in diabetes-mediated vascular dysfunction (for review see [2]) has been shown in animal models $[35,36]$. Moreover, PKC activation is involved in the regulation of eNOS and endothelin-1 expression under diabetic conditions [37, 38]. Thus, although PKC might activate $\mathrm{NAD}(\mathrm{P}) \mathrm{H}$ oxidase in diabetes, the underlying mechanisms [24, $25,26,39]$ need further investigation.

Thromboxane synthase. The thromboxane synthase produces prostaglandin endoperoxides in a cage radical mechanism [40]. Interestingly, in the aortas of diabetic rabbits impaired endothelium-dependent relaxation is associated with increased production of thromboxane $\mathrm{A}_{2}$ or its precursor prostanoid, prostaglandin endoperoxide (PGH; [41]). Further evidence for the involvement of thromboxane synthase in diabetes-associated vascular complications comes from the findings that inhibitors of the thromboxane synthase prevented renal injury [42] and retinopathy $[43,44]$ in diabetic animals. In humans, inhibitors of the thromboxane synthase were described as being beneficial against diabetic nephropathy [45]. Furthermore, in the aortae of diabetic rats the selective inhibitor of thromboxane $\mathrm{A}_{2}$-prostaglandin $/ \mathrm{H}_{2}$ receptors, ONO-3708, abolished acetylcholine-induced contraction and prevented the diabetes-associated impairment of endothelium-dependent blood vessel relaxation ([46]). In agreement with these results endothelial thromboxane $\mathrm{A}_{2}$ formation was reported under hyperglycaemic conditions $[47,48]$.

Superoxide dismutase (SOD). SOD represents one of the major ROS-defending enzymes. However, it is noteworthy that during the SOD-mediated conversion of the $\mathrm{O}_{2}{ }^{-}-$to $\mathrm{H}_{2} \mathrm{O}_{2}$ a further ROS is produced. These two ROS differ greatly in terms of their physical properties and biological action. $\mathrm{O}_{2}{ }^{\circ-}$ cannot freely penetrate the cell membrane and would need to pass through certain ion channels $\left(\mathrm{Cl}^{-}\right.$channels) $[49,50]$, while $\mathrm{H}_{2} \mathrm{O}_{2}$ can easily enter through the cell membrane. Thus, the extracellular conversion of $\mathrm{O}_{2}{ }^{-}-$to $\mathrm{H}_{2} \mathrm{O}_{2}$ by extracellular SOD, that is bound on endothelial surface matrix by heparansulfate residues, might generate a membrane penetrating molecule that transduces extracellular oxidative stress into the cells. While this aspect has been rarely discussed, SOD was widely used to prevent hyperglycaemic/diabetic vascular dysfunction $[11,51,52,53,54$, 55]. Importantly, most of these studies were focussed on acute hyperglycaemia, endothelial reactivity or apoptosis [53], whereas the effect of SOD on vascular adaptation and changes in response to diabetic conditions has not been investigated so far. Because SOD and catalase are able to restore completely the dilatory response to acetylcholine in diabetic animals, it is tempting to speculate on an involvement of $\mathrm{O}_{2}{ }^{\circ-}$ and $\mathrm{H}_{2} \mathrm{O}_{2}$ in the impairment of endothelium dependent dilation in diabetes $[55,56]$.

While hyperglycaemia changes endothelial SOD expression [57], the expression of SOD in diabetic arteries was found to be either unchanged, increased or decreased depending on disease duration $[58,59,60]$. Nevertheless, the importance of SOD as a defence 
protein against diabetes-associated reduction of blood vessel relaxation is apparent from the exciting finding that gene transfer of CuZnSOD and MnSOD reversed endothelial dysfunction aortae of diabetic rabbits [61]. Thus, considering the possible alterations in SOD expression, its possible beneficial effects on diabetic endothelial dysfunction and the different effects of its substrate $\mathrm{O}_{2}{ }^{-}-$and the resulting product $\mathrm{H}_{2} \mathrm{O}_{2}$, the role of SOD in vascular oxidative defence and in the development of vascular dysfunction needs to be explored in more detail.

Endothelial nitric oxide synthase (eNOS). Despite attenuation of $\mathrm{NO}^{\bullet}$ production [62] and its bioactivity $[11,63]$ by high glucose concentrations, the expression of endothelial nitric oxide synthase (eNOS, NOS III) has been found to be upregulated in endothelial cells under such conditions [64]. In line with these findings, increased eNOS expression was found in the aortae of streptozotocin diabetic rats [10], while in the same model a reduced eNOS protein content was found in the skeletal muscle [65] and in the heart [66]. No change in eNOS expression was seen in diabetic rats $(\mathrm{BB} / \mathrm{W})$ [67]. There is evidence that the reduced $\mathrm{NO}^{\bullet}$ production by eNOS in diabetes [68] might be due to its substrate L-arginine [53, 69], a posttranslational modification of the eNOS on the Akt phosphorylation site [71] and the lack of its coenzyme tetrahydrobiopterin $[53,70]$. The latter results from decreased expression and, activity of GTP-cyclohydrolase I, the first and rate limiting enzyme in the de novo biosynthesis of $\mathrm{BH}_{4}$, in diabetic cells [72]. In studies on the purified enzyme the lack of either tetrahydrobiopterin or L-arginine or both results in eNOS uncoupling [73, 74] which is indicated by a $\mathrm{Ca}^{2+}$-dependent formation of $\mathrm{O}_{2}{ }^{\bullet-}[75]$. It has been suggested that $\mathrm{ONOO}^{-}$oxidises $\mathrm{BH}_{4}$, which can uncouple eNOS in vivo [76] and thereby contributes in the endothelium to oxidative stress and endothelial dysfunction through at least 3 mechanisms. First, the enzymatic production of $\mathrm{NO}^{\bullet}$ is diminished, thus the system lacks $\mathrm{NO}^{\bullet}$ as an essential mediator molecule. Second, the enzyme produces $\mathrm{O}_{2}{ }^{-}-$and thus, contributes to oxidative stress. Finally, it is likely that eNOS becomes partly uncoupled, so that both $\mathrm{O}_{2}{ }^{-}$ and $\mathrm{NO}^{\bullet}$ are produced simultaneously. Under these circumstances, eNOS could become a $\mathrm{ONOO}^{-}$generator, leading to a dramatic increase in oxidative stress. Recently, the production of $\mathrm{O}_{2}{ }^{-}-$by eNOS has been demonstrated in streptozotocin-diabetic rats [10]. According to this report eNOS-mediated $\mathrm{O}_{2}{ }^{-}-$production in diabetes critically depends on PKC activation which supports the findings of PKC activation as a crucial step in the development of diabetic vascular complications [35, 77-79].

A decline in $\mathrm{NO}^{\bullet}$ bioavailability could be caused by reduced expression of eNOS [80], a lack of substrate or cofactors of eNOS [73], increased $\mathrm{NO}^{\bullet}$ scavenging by $\mathrm{O}_{2}^{\bullet-}[81,82]$ and alterations of cellular signalling so that eNOS is not appropriately active $[55,83]$.

Mitochondria. Pathological changes caused by diabetes are consequences of hyperglycaemia-induced mitochondrial superoxide overproduction [78, 79]. Under hyperglycaemic conditions, mitochondrial $\mathrm{O}_{2}{ }^{\circ-}$ has been shown to activate sorbitol accumulation by the aldose-reductase pathway [84] resulting in the activation of PKC $[77,78]$ which, in turn, is responsible for the generation of AGEs and endothelial dysfunction. The metabolism of D-glucose through the sorbitol pathway has been reported to affect the oxidative potential of endothelial cells $[85,86]$. This hypothesis suggests that an enhanced catabolism of D-glucose through the sorbitol pathway yields a status of pseudohypoxia (increased NADH concentrations), activates PKC [84] and subsequent downstream signalling. In addition, mitochondrial superoxide overproduction inhibits glyceraldehyde-3phosphate dehydrogenase (GAPDH) activity and activates the hexosamine pathway, presumably by diverting the upstream metabolite fructose-6-phosphate from glycolysis to glucosamine formation [87]. In heart failure it has been shown that mitochondria complex $\mathrm{I}$ is the predominant source of the primary radical $\mathrm{O}_{2}{ }^{-}-$[88] which, in turn, is converted to $\mathrm{H}_{2} \mathrm{O}_{2}$ and the potent reactive species $\mathrm{HO}^{\bullet}$ [89].

In addition to the role of mitochondria as a source of ROS, the mitochondria themselves can be damaged by oxidants. ROS mediate mitochondrial DNA damage, alterations in gene expression and mitochondrial dysfunction in cultured vascular ECs and SMCs [90].

\section{Targets of ROS}

Small guanine nucleotide binding proteins. Small guanine nucleotide binding proteins (G-proteins) exert GTPase activity and are proposed to serve as mediators of ROS (Fig. 2). The Rho GTPase family is a member of the Ras superfamily [91] and consists of at least 14 distinct proteins ranging from 20 to 24 $\mathrm{kDa}$, which can be additionally subdivided. Small Gproteins of the Rho subfamily, such as Rho, Rac and CDC42 are involved in many cellular processes, including proliferation, differentiation [92], migration, cytoskeletal organisation and signal transduction $[93,94]$ and might play a crucial role in the development of cardiovascular complications. In certain cell types, Rho, which probably mediates ROS production, triggers the activation of the proinflammatory nuclear transcription factor $(\mathrm{NF}-\varkappa \mathrm{B})$ in response to hyperglycaemia and AGEs [95]. While Rac has been shown to constitute a mediator of the oxidant-initiated signalling $[96,97]$, it is also a target for $\mathrm{H}_{2} \mathrm{O}_{2}$, 

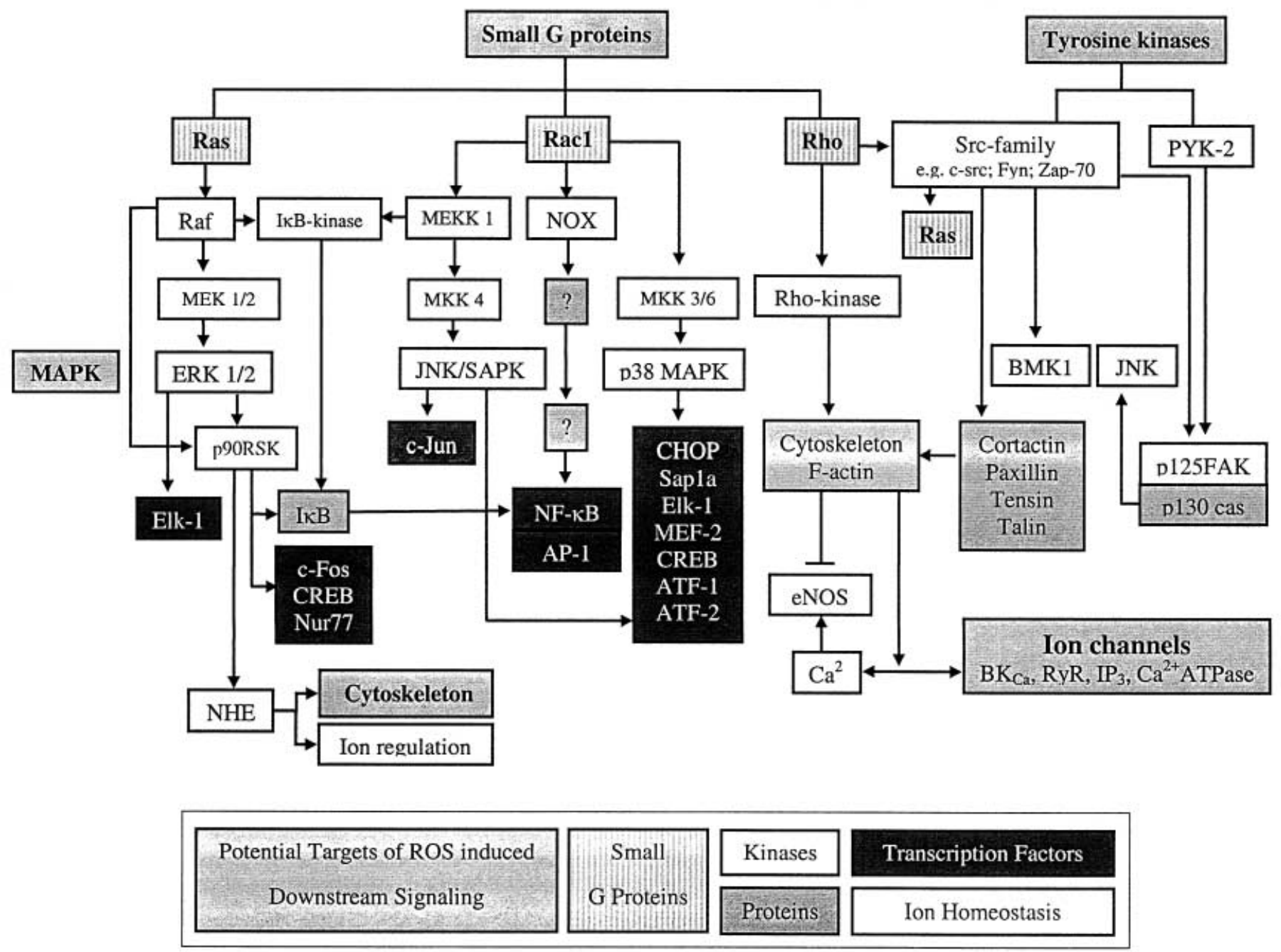

Fig. 2. Downstream targets of ROS under diabetic condition

$\mathrm{NO}^{\bullet}$ and $\mathrm{O}_{2}^{\bullet-}$ [13]. In addition, ROS could directly activate Ras that, in turn, initiates activation of the mitogen-activated protein kinase (MAPK) pathway [13]. The sites of oxidative attack of H-Ras are the cysteine residues contributing to membrane binding and Cys-118. Modification of the latter affects the binding of GTP and GDP on H-Ras [98, 99]. The Rho family member Rac1 is a regulatory component of the NAD(P)H oxidase (see above) in many cell types, including neutrophils and cells of the vascular wall. Rac triggers the clustering of the subunits of $\mathrm{NAD}(\mathrm{P}) \mathrm{H}$ oxidase to form the functional multienzyme complex [14].

These cytosolic GTP-binding proteins are isoprenylated and some are additionally palmitoylated on cysteine residues [100], allowing translocation to the cell membrane as the initial step in their activation. The beneficial effects of 3-hydroxy-3-methylglutarylCoA reductase inhibitors (statins) which block geranylgeraniol synthesis in hypertension and heart fail- ure, could be because of the inhibition of Rho proteins in the heart. Indeed, inhibition of Rac1 isoprenylation by statins inhibits the release of reactive oxygen species in endothelial cells [101]. In vascular smooth muscle cells, Rho promotes cell-cycle progression and proliferation, which are central events in the pathogenesis of vascular lesions, including postangioplasty restenosis, transplant arteriosclerosis and vein craft occlusion. The molecular mechanism is attributable, in part, to Rho-induced destabilisation of the cyclin-dependent kinase inhibitor p27kip1 [102]. Recent studies also suggest that statins exert additional anti-inflammatory and antioxidant effects on the vascular wall $[101,102]$.

Furthermore, Rho plays an important role in the regulation of endothelial function and gene expression [103]. Besides upregulating preproendothelin-1 expression, RhoA negatively regulates the production of endothelium-derived $\mathrm{NO}^{\bullet}$ by Rho-induced changes in the endothelial actin cytoskeleton [104].

Small guanine nucleotide binding proteins and the cytoskeleton. Small G-proteins like RhoA, Rac and $\mathrm{CDC} 42$ represent key regulators of the actin cytoske- 
leton [105] and induce assembly of stress fibres and focal adhesions (RhoA), membrane ruffling, redistribution of actin fibres and an increase in the total amount of f-actin (Rac) and filopodia formation (CDC42). $\mathrm{O}_{2}{ }^{-}-$induced changes in the actin cytoskeleton (Fig. 2), such as the polymerisation of f-actin to stress fibres with a concomitant increase in f-actin, are associated with reinforced tyrosine phosphorylation. The actin reorganisation in response to $\mathrm{O}_{2}{ }^{\circ}$ is thought to be mediated by changes in the redox state of actin or its regulatory (sequestering or capping) proteins $[14,102]$. Alternatively, $\mathrm{O}_{2}{ }^{-}$might be involved in cytoskeletal changes by the activation of $\operatorname{Rac}[14,106]$. In line with this hypothesis, overexpression of Rac in human and mouse aortic ECs induces an increase in f-actin content and actin reorganisation which is accompanied by the $\mathrm{O}_{2}{ }^{-}-$production [102].

Increasing evidence points to a central role of Rho in the regulation of the actin cytoskeleton by mediating changes in cell shape, contractility and motility. The functional linkage between Rho and the cytoskeleton was further supported by the findings that a direct inhibition of Rho by Clostridium botulinum C3 transferase and the disruption of the endothelial actin cytoskeleton by cytochalasin $\mathrm{D}$ increase expression and activity of aortic eNOS [107].

Clinical trials on statins point to a beneficial potential of these drugs in cardiovascular diseases that exceeds their effect on cholesterol-lowering [102]. Because statins also inhibit isoprenoid synthesis [102] which is required for the posttranslational modification of Rho it is tempting to speculate that at least parts of their action are due to direct effects on Rho which is required for basal expression of preproendothelin-1 in vascular endothelial cells. In addition statins inhibit preproendothelin-1 expression by blocking Rho geranylgeranylation [103]. Hence, inhibition of Rho is an important effect of the statins independently to their cholesterol-lowering properties. Therefore, small G proteins like Rac and Rho are likely to be involved in the development of diabetes and ROS-associated vascular complications.

Protein kinases. ROS activate several proteins of important signalling cascades that individually change cell function and gene expression.

The activation of PKC represents a hallmark in the development of vascular complications in diabetes mellitus (for review see Idris et al. [2]). Among the $\mathrm{PKC}$ family, several isoenzymes have been shown to contribute to insulin signalling (e.g. PKC- $\theta$ and PKC- $\varepsilon$ ) and insulin-stimulated D-glucose uptake (PKC- $\varsigma$ and $\mathrm{PKC}-\lambda$ ), while others (most prominently $\mathrm{PKC}-\beta$ ) are involved in the development of diabetes-linked complications. This review consequently focuses on other potential signalling kinases (Fig.2; Table 1) that might constitute additional targets in the pathology of diabetes.
Among the growing number of ROS-sensitive signalling cascades, the activation of serine/threonine protein kinases such as mitogen-activated protein kinases (MAPKs) or Akt kinase (PKB) have been described. A member of the MAPK family, the extracellular signal-regulated kinase (ERK1/2) was found to be activated by exogenous $\mathrm{H}_{2} \mathrm{O}_{2}$ and endogenously generated ROS [108] by PKC, Raf-1 and MEK1 [109]. Based on these findings, it was hypothesised that reactive oxygen species might activate MAPK in vascular smooth muscle cells as $\mathrm{O}_{2}{ }^{-}-$but not $\mathrm{H}_{2} \mathrm{O}_{2}$ stimulated activation of MAP kinase, which if due to $\mathrm{O}_{2}{ }^{\circ}-$ was PKC dependent [13]. On the contrary, Guyton et al. [110] demonstrated ERK activation as well as a moderate stimulation of c-Jun N-terminal kinase (JNK) and p38 MAPK by $\mathrm{H}_{2} \mathrm{O}_{2}$ in several cell types. In line with these findings, an inhibition of $\mathrm{p} 38$ MAPK was found to ameliorate diabetes-associated vascular dysfunction in the rat mesenteric microcirculation [111]. Another MAPK, BMK1, a downstream target of c-src, seems to be specifically redox-sensitive. In smooth muscle cells it has been observed that in response to several different agonists BMK1 was stimulated to the greatest extent by $\mathrm{H}_{2} \mathrm{O}_{2}$ with a relative potency of $\mathrm{H}_{2} \mathrm{O}_{2}>>>$ PDGF $>$ P$\mathrm{MA}=\mathrm{TNF}-\alpha[112]$.

Stress-Activated Protein Kinases (SAPK), including JNKs and p38 MAPK, are regulated by members of the Rho-family and are also sensitive to redox modulation [113]. JNKs and their downstream target c-Jun are stimulated by $\mathrm{H}_{2} \mathrm{O}_{2}$ during ROS -induced apoptosis of endothelial cells. The Akt kinase, a downstream effector of phosphoinositide 3-kinase (PI3-kinase), is involved in antiapoptotic signalling [114] and regulated by ROS in AngII-stimulated SMCs [115]. In endothelial cells, activation of Akt has been proposed to facilitate a protective effect against shear stress and apoptosis [108] and to reduce eNOS activity by posttranslational modification [71]. Interestingly, Rac1 is a further downstream target of PI3-kinase [108] and, thus, a stimulation of PI3-kinase might initiate Rac1-mediated NAD $(\mathrm{P}) \mathrm{H}$ oxidase activation resulting in a simultaneous formation of ROS and Akt stimulation.

A growing body of evidence also suggests that ROS affect various protein tyrosine kinases (PTKs). Fyn, a member of the src-family, has been shown to be responsible for $\mathrm{H}_{2} \mathrm{O}_{2}$-mediated activation of Ras and $90 \mathrm{kDa}$ of ribosomal S6 kinases (p90RSK), in addition, Fyn might regulate Ras and, in turn, p90RSK, in a redox-sensitive manner [116]. Hence, $\mathrm{H}_{2} \mathrm{O}_{2}$ mediated BMK1 activation requires c-Src (p60Src) $[13,116,117]$ indicating that the c-Src / BMK1 signalling pathway is redox-sensitive. In addition to p60Src, p56Lck, p59Fyn, Syk, ZAP-70 [13] and the $\mathrm{Ca}^{2+}$-sensitive proline-rich tyrosine kinase Pyk2 [118] are also affected by ROS. In ROS-treated endothelial cells tyrosine phosphorylation of the Pyk2 downstream 
Table 1. Redox-sensitive Protein kinases / phosphatases. Effects due to $\mathrm{H}_{2} \mathrm{O}_{2}$; taken from Allen and Tresini [222]

\begin{tabular}{|c|c|c|}
\hline Kinase/Phosphatase & Cell type & Effect \\
\hline $\begin{array}{l}\text { ERK pathway } \\
\text { (MAP-kinase) }\end{array}$ & $\begin{array}{l}\text { Bovine tracheal monocytes } \\
\text { Human neutrophils } \\
\text { Jurkat T cells } \\
\text { NIH3T3 } \\
\text { Rat alveolar macrophages } \\
\text { Rat arterial smooth muscle cells } \\
\text { Rat cardiac myocytes } \\
\text { Rat smooth muscle (A7r5) } \\
\text { Rat vascular smooth muscle } \\
\text { Rat ventricular myocytes }\end{array}$ & $\begin{array}{l}\text { Phosphorylation of ERK-1/2 } \\
\text { Increased phosphorylation of ERK-1/2 } \\
\text { Activated ERK-1/2 } \\
\text { Activated ERK-2 } \\
\text { ERK-1/2 phosphorylation } \\
\text { ERK-1/2 phosphorylation } \\
\text { Activated ERK-2 } \\
\text { ERK-1/2 phosphorylation } \\
\text { ERK-1/2 phosphorylation; No effect } \\
\text { Activated ERK-1/2 }\end{array}$ \\
\hline BMK-1/ERK-5 & $\begin{array}{l}\text { Mouse fibroblasts } \\
\text { Rat vascular smooth muscle } \\
\text { Human vascular smooth muscle } \\
\text { Human umbilical vein endothelial cells } \\
\text { Fibroblasts }\end{array}$ & $\begin{array}{l}\text { Activated } \\
\text { Activated } \\
\text { Activated } \\
\text { Activated } \\
\text { Activated }\end{array}$ \\
\hline p38 (MAP kinase) & $\begin{array}{l}\text { Human umbilical vein endothelial cells } \\
\text { Mouse NIH 3T3 } \\
\text { Rat alveolar macrophages } \\
\text { Rat arterial smooth muscle cells } \\
\text { Rat vascular smooth muscle }\end{array}$ & $\begin{array}{l}\text { Activated } \\
\text { Increased phosphorylation } \\
\text { Increased phosphorylation } \\
\text { Increased phosphorylation } \\
\text { Increased phosphorylation }\end{array}$ \\
\hline MEK & Bovine tracheal monocytes & Increased activity of MEK1 \\
\hline Raf-1 & Bovine tracheal myocytes & Increased activity \\
\hline $\mathrm{PKC}$ & Human Jurkat T cells & Increased activity \\
\hline p5 $6^{\text {lck }}$ & $\begin{array}{l}\text { Human Jurkat T cells } \\
\text { Rat 208F fibroblasts } \\
\text { Increased phosphotyrosine }\end{array}$ & $\begin{array}{l}\text { Phosphorylation Tyr-394, Tyr505 } \\
\text { Stimulated activity }\end{array}$ \\
\hline Phosphatase Ser/Thr & $\begin{array}{l}\text { Human erythrocytes } \\
\text { Sheep erythrocytes }\end{array}$ & $\begin{array}{l}\text { Increased activity of membrane bound form } \\
\text { Increased activity of membrane bound form }\end{array}$ \\
\hline Phosphatase Tyr & Human fibroblasts (EK4) & Increased mRNA \\
\hline
\end{tabular}

target p130cas, of a focal adhesion kinase (p125FAK) and of paxillin is increased [119]. The cytosolic tyrosine kinase p125FAK, a non-receptor protein-tyrosine kinase, plays a central role in the regulation of the actin cytoskeletal organisation by phosphorylating components of focal adhesion, such as tensin, paxillin and talin. Furthermore, p125FAK regulates interactions of integrins with the cytoskeleton and with the extracellular matrix or both. Thus, stimulation of p125FAK by ROS mediates reversible changes in cell shape and morphology, reorganisation of the cytoskeleton and redistribution of cell-surface adhesion proteins [119]. The involvement of high glucose concentration in ROS and tyrosine kinase activation hyperglycaemia is further supported by findings that genistein, an antioxidant and non-selective inhibitor of tyrosine kinases, prevented glucose- mediated atherogenic modification of low density lipoprotein [120].

Besides a direct activation of PTKs by ROS, protein tyrosine phosphatases (PTPs) seem to be prime candidates for ROS signalling. Most PTPs contain conserved cysteine residues within their active domains [108]. Their oxidation might affect the biological activity of the phosphatase. Attenuated PTP activity shifts the balance of protein tyrosine phosphorylation and dephosphorylation towards a status of enhanced protein tyrosine phosphorylation of cellular targets of PTKs, such as ERKs and SAPKs.

From the above it is apparent that a variety of ROS-sensitive protein kinases, such as PKC and PTKs, is involved in vascular cell dysfunction. Even isoforms of these enzymes could constitute promising 
selective targets for therapeutic intervention against diabetes-associated vessel complications.

Matrix metalloproteinases (MMPs). MMPs, also termed matrixins, are members of a family of $\mathrm{Zn}^{2+}$ and $\mathrm{Ca}^{2+}$-dependent endopeptidases, which are essential for cellular migration and tissue remodelling [121]. They have been shown to play an important role in atherosclerosis and angiogenesis, whereas little is known about the effects of hyperglycaemia on MMP regulation in vascular cells [4]. The expression and activity of 92-kDa (MMP-9) gelatinase are increased in vascular tissue and plasma of diabetic models [4] and in cultured bovine aortic ECs (but not in SMCs or macrophages) after long-term exposure to high D-glucose [4]. The rise in enzyme activity is markedly reduced by treatment with antioxidants such as polyethylene glycol-SOD, superoxide dismutase and N-acetyl-L-cysteine, but not by inhibitors of PKC [4], although PMA, an PKC activator, increases MMP-9 expression in various cell types, including vascular endothelial cells [122]. The MMP-9 promoter region contains binding sites for the redox-sensitive transcription factors NF- $\varkappa$ B and AP-1 [123] indicating their involvement in ROS-induced MMP-9 transcription and activity [124].

MMP-2 and MMP-9, which are regulated by oxidative stress [125], are actively synthesised in atheromatous plaques [126] and appear to contribute to monocyte invasion and vascular SMC migration. Therefore, any derangement of MMP regulation is considered a critical factor in the development of vascular complications [127] including acute myocardial infarction and unstable angina [128]. It has also been established that MMP-9 activity is required for angiogenesis and neovascularisation, which constitute important elements in the mechanisms of plaque progression in atherosclerosis [129].

So far no causal link has been provided between the disruption of the cytoskeleton and the expression of MMPs. A recent study showed disruption of the actin cytoskeleton induced with an antibody against $\alpha_{5} \beta_{1}$ integrin increased expression of MMP- 1 in rabbit synovial fibroblasts [130]. Possibly Rac becomes activated during cytoskeletal reorganisation resulting in increased $\mathrm{NAD}(\mathrm{P}) \mathrm{H}$ oxidase activity and recruitment of NF- $x$ B [131]. Thereby IL- $1 \alpha$, an autocrine inducer of MMP-1 expression, is induced. Alternatively, in endothelial cells the disruption of the cytoskeletal network has been shown to affect subcellular $\mathrm{Ca}^{2+}$ signalling $[132,133]$ subsequently regulating a variety of signal transduction pathways and transcription factors [134, 135, 136, 137] (Fig.3). Thus, a contribution of altered spatial $\mathrm{Ca}^{2+}$ signalling in MMP expression in response to cytoskeleton disruption appears possible.

Any such enhanced MMP activity could be critical for diabetic microvascular complications. Although

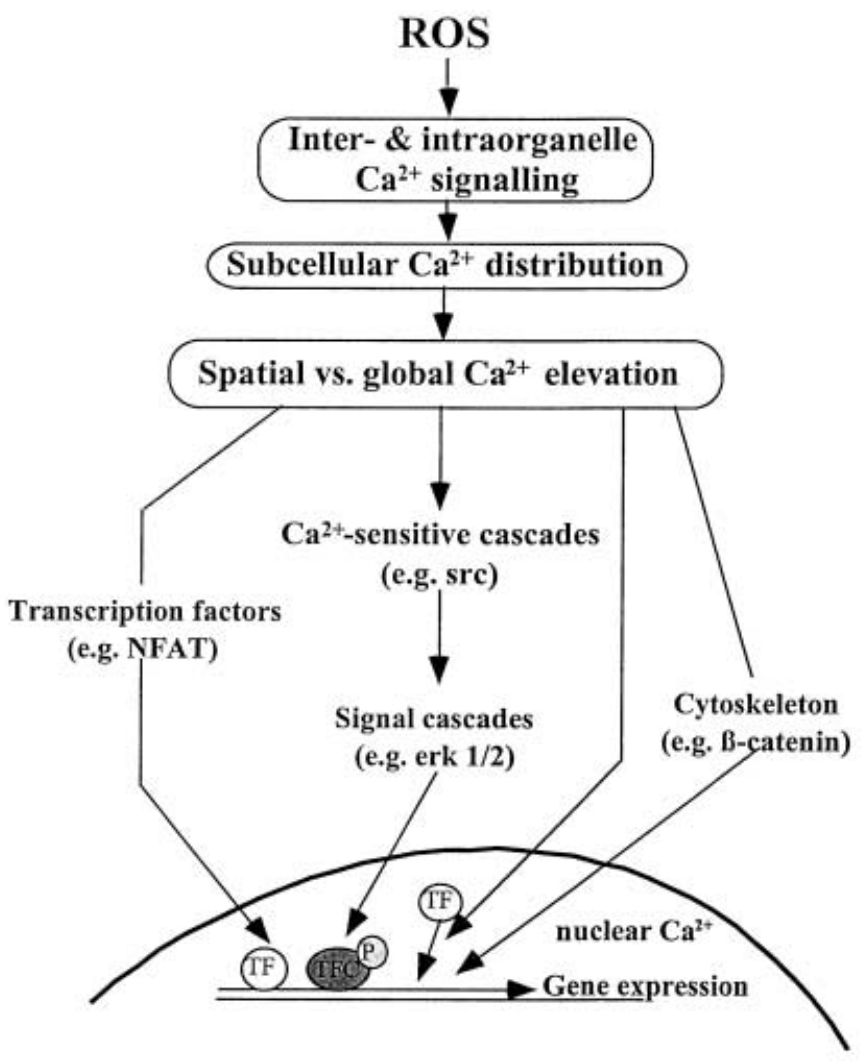

Fig. 3. Possible effects of ROS on intracellular $\mathrm{Ca}^{2+}$ handling and subcellular $\mathrm{Ca}^{2+}$ distribution and its consequences for $\mathrm{Ca}^{2+}$ modulated gene expression. The production of ROS due to diabetic-associated risk factors initiates changes in interand intra-organelle $\mathrm{Ca}^{2+}$ handling and disturbances in the subcellular $\mathrm{Ca}^{2+}$ distribution. Due to the lack of the formation of locally insulated $\mathrm{Ca}^{2+}$ gradients for specific activation of $\mathrm{Ca}^{2+}$ sensitive gene regulation, the whole $\mathrm{Ca}^{2+}$-sensitive transcription machinery is ubiquitous activated, resulting in uncontrolled activation of $\mathrm{Ca}^{2+}$-sensitive gene expression

the exact mechanisms that link diabetes and ROS with MMP expression are not fully understood, additional studies are necessary to further define MMPs as potential therapeutic targets in diabetic blood vessel dysfunction.

Ion homeostasis. Ion channels play a crucial role in vascular homeostasis. $\mathrm{K}^{+}$-current that hyperpolarises the cell reduces $\mathrm{Ca}^{2+} \mathrm{L}$-type channel activity and relaxes smooth muscle cells (SMCs), whereas the inhibition of $\mathrm{K}^{+}$channels facilitates the activation of the $\mathrm{Ca}^{2+} \mathrm{L}$-type channels and therefore SMCs contraction [138]. In endothelial cells (ECs) the impact of $\mathrm{K}^{+}$ channels on $\mathrm{Ca}^{2+}$-entry is opposite to that found in SMCs, because $\mathrm{K}^{+}$channel-mediated membrane hyperpolarisation facilitates $\mathrm{Ca}^{2+}$ entry through so called store-operated $\mathrm{Ca}^{2+}$ channels (i.e. non-voltage gated $\mathrm{Ca}^{2+}$ channels). However, an increase in endothelial $\mathrm{Ca}^{2+}$ concentration primarily activates eNOS, prostacyclin synthesis and formation of endothelium-derived hyperpolarising factor(s) $(\mathrm{EDHF}(\mathrm{s}))$, 
leading to blood vessel relaxation [139]. Recently, endothelial $\mathrm{K}^{+}$outward currents were shown to constitute a EDHF-like mechanism due to locally raised $\mathrm{K}^{+}$concentrations in the direct vicinity of smooth muscle $\mathrm{K}^{+}$channels [140]. Thus, while the effect of $\mathrm{K}^{+}$channel activation to cellular $\mathrm{Ca}^{2+}$ concentration differs in ECs and SMCs, the impact of $\mathrm{K}^{+}$channels for global vascular response (i.e. relaxation, contraction) is identical. The potentially diminishing effect of diabetes mellitus on $\mathrm{K}^{+}$channel activity or activation involved in EDHF-mediated blood vessel relaxation has been shown in streptozotocin-induced diabetic rats [141, 142]. Furthermore, reduced activation of ATP-sensitive $\mathrm{K}^{+}$channels leading to membrane depolarisation and vasoconstriction has also been described in diabetic rats $[143,144]$ indicating that besides $\mathrm{NO}^{\circ}$ the formation and the effect of EDHF can also be impaired in diabetes.

In ECs the effect of ROS on ion channels (Fig. 2) and subsequent ion signalling considerably relies on the oxygen species and can be varied depending on acute as opposed to chronic actions. Peroxides such as $\mathrm{H}_{2} \mathrm{O}_{2}$ or tertiary-butylhydroperoxide $(\mathrm{t}-\mathrm{BuOOH})$ appear to reduce the $\mathrm{Ca}^{2+}$ influx [145]. Possibly linked to the duration of treatment and usage of media supplements, hyperglycaemia was found to enhance [146] or to impair [147] intracellular $\mathrm{Ca}^{2+}$ concentrations upon agonist stimulation due to the accumulation of $\mathrm{O}_{2}{ }^{-}-$. In line with the latter findings, endothelial $\mathrm{Ca}^{2+}$ signalling was found to be impaired in diabetic mice $[148,149]$. Remarkably, in myocytes hyperglycaemia was found to increase cytosolic free $\mathrm{Ca}^{2+}[150]$, while chronic diabetes impaired L-type $\mathrm{Ca}^{2+}$ channel activity [151].

Hence, in ECs t-BuOOH has been shown to increase the opening probability of non-selective cation channels of $30 \mathrm{pS}$ [152] and of Trp3 [153], resulting in membrane depolarisation. In ventricular myocytes, extracellularly produced ROS activate $\mathrm{Ca}^{2+}$-dependent nonselective cation channels without any change in cytosolic $\mathrm{Ca}^{2+}$ concentration [154]. Furthermore, membrane depolarisation can be due to an inhibition by $\mathrm{H}_{2} \mathrm{O}_{2}$ of the intermediate conductance $\mathrm{K}_{\mathrm{Ca}}$ channel [155]. In human umbilical vein endothelial cells an enhanced $\mathrm{O}_{2}{ }^{\circ}-$ production by Rac-dependent $\mathrm{NAD}(\mathrm{P}) \mathrm{H}$ oxidase activation occurs as a result of membrane depolarisation [156]. As pointed out above, the formation of $\mathrm{O}_{2}{ }^{--}$is of particular impact in endothelial cells regarding the local $\mathrm{NO}^{\bullet}$ formation because these radicals can react to form $\mathrm{ONOO}^{-}$ which, in turn, inhibits $\mathrm{Ca}^{2+}$ influx [157] and the activity of $\mathrm{BK}_{\mathrm{Ca}}$ channels [158]. Thus, it is reasonable that during certain forms of oxidative stress (peroxides, $\mathrm{ONOO}^{-}$) membranes become depolarised resulting in an attenuated driving force for $\mathrm{Ca}^{2+}$ and in reduced $\mathrm{Ca}^{2+}$-entry. In view of the importance of $\mathrm{Ca}^{2+}$-entry for eNOS activation [159, 160], one could assume that $\mathrm{t}-\mathrm{BuOOH}$-mediated membrane depolarisation reduces eNOS activation in response to $\mathrm{Ca}^{2+}$ elevating agonists.

There is increasing evidence that, in addition to channels in the plasma membrane, $\mathrm{Ca}^{2+}$ channels in organelles (i.e. endoplasmic reticulum and mitochondria) are common targets of several forms of ROS. The mechanisms by which ROS affect $\mathrm{Ca}^{2+}$ unloading of the endoplasmic reticulum are not clear but could be related to changes in the activity of sarcoplasmic/ endoplasmic reticulum $\mathrm{Ca}^{2+}$ ATP-ases (SERCAs) [161], $\mathrm{IP}_{3}$ receptors [162] and ryanodine receptors (RyR) [163]. The latter is stimulated in skeletal muscle by $\mathrm{H}_{2} \mathrm{O}_{2}$ [164] and in cardiac muscle by $\mathrm{HO}^{\circ}$ [165]. Furthermore, oxidants (e.g. t-BuOOH) seem to reversibly increase the permeability of the inner mitochondrial membrane by pore formation, leading to $\mathrm{Ca}^{2+}$ release from the mitochondria [166, 167]. Most of these studies have relied essentially upon the use of isolated mitochondria loaded with $\mathrm{Ca}^{2+}$, and then exposed to oxidants. On the contrary, the work of Jornot et al. [168] in intact cells demonstrated higher $\mathrm{Ca}^{2+}$ concentration in the mitochondria, which was preceded by a rise in cytosolic free $\mathrm{Ca}^{2+}$ concentration. This $\operatorname{ROS}\left(\mathrm{H}_{2} \mathrm{O}_{2}\right.$, or $\left.\mathrm{O}_{2}{ }^{\bullet-}\right)$ initiated increase in mitochondrial $\mathrm{Ca}^{2+}$ concentration resulted from a transfer of $\mathrm{Ca}^{2+}$ by the electrogenic uniporter, and a decrease in the rate of $\mathrm{Ca}^{2+}$ efflux from the mitochondria via the $\mathrm{Ca}^{2+} / \mathrm{Na}^{+}$exchanger.

In view of the importance of ion channels for vascular cell function, their contribution to diabetes-associated complications needs more attention in order to understand whether ion channels are attacked by ROS directly or by one of their downstream targets. Increased ROS production and subsequent alterations in intracellular $\mathrm{Ca}^{2+}$ concentration in endothelial cells, smooth muscle cells and platelets [169] are the cause of many cardiovascular diseases. While most studies are focussed on global $\mathrm{Ca}^{2+}$ signalling $[170,171,172,173]$, we could describe changes in subcellular (perinuclear and subplasmalemmal) $\mathrm{Ca}^{2+}$ distribution in smooth muscle cells from diabetic patients [174] (Fig. 3). This study is in line with findings in the rat tail artery, where hyperglycaemia was found to initiate alterations of cytosolic $\mathrm{Ca}^{2+}$ signalling [175]. This was accompanied by ROS-triggered restructuring of the cytoskeleton and the endoplasmic reticulum. Thus, under pathological conditions accompanied by increased ROS production, changes in subcellular $\mathrm{Ca}^{2+}$ signalling could represent an early target for altered endothelial function that results in changes in cell function (e.g. eNOS, [51, 53, 70, 176]) and gene expression [37, 177].

Transcriptional regulation. In diabetic patients activation by hyperglycaemia, AGEs, oxidised LDL and ROS of the inducible transcription activator NF- $x \mathrm{~B}$ could promote atherosclerosis and its rapid progression $[28,84,178,179]$. NF- $x \mathrm{~B}$ that has been shown to 
Table 2. Redox-sensitive Regulatory factors. Effects due to $\mathrm{H}_{2} \mathrm{O}_{2}$; taken from Allen and Tresini [222]

\begin{tabular}{|c|c|c|}
\hline Gene or protein & Cell type & Effect \\
\hline $\mathrm{NF}-\varkappa \mathrm{B}$ & $\begin{array}{l}\text { Human endothelial cells (ECV304) } \\
\text { Human Jurkat T-cells } \\
\text { Human microvascular endothelial cells } \\
\text { Human T cells (peripheral) } \\
\text { Jurkat T cells } \\
\text { Mouse fibroblasts (3T3) } \\
\text { Mouse macrophages (J774A.1) } \\
\text { Pig vascular endothelium } \\
\text { Rat heart endothelial cells }\end{array}$ & $\begin{array}{l}\text { Activated } \\
\text { Activated } \\
\text { Increased DNA binding } \\
\text { Decreased DNA binding } \\
\text { Activated } \\
\text { Activated } \\
\text { Activated } \\
\text { Increased DNA binding } \\
\text { Activated }\end{array}$ \\
\hline $\mathrm{I} \varkappa \mathrm{B}$ & Human endothelial cells (ECV304) & Stimulated degradation of $\mathrm{I} \varkappa \mathrm{B} \alpha$ \\
\hline NF-AT (protein) & $\begin{array}{l}\text { Jurkat T cells } \\
\text { Human T cells (peripheral) }\end{array}$ & $\begin{array}{l}\text { Decreased transcriptional activation by NF-AT } \\
\text { Decreased DNA binding }\end{array}$ \\
\hline AP-1 & $\begin{array}{l}\text { Human microvascular endothelial cells } \\
\text { Human T cell (peripheral) } \\
\text { Big vascular endothelium } \\
\text { Rat embryo glial cells } \\
\text { Rat heart endothelial cells }\end{array}$ & $\begin{array}{l}\text { Increased DNA binding } \\
\text { Decreased DNA binding } \\
\text { Increased DNA binding } \\
\text { Increased binding to TRE } \\
\text { Activated }\end{array}$ \\
\hline Jun protein & Rat vascular smooth muscle & Increased protein \\
\hline c-fos & Rat vascular smooth muscle & Increased mRNA \\
\hline Fos protein & Rat vascular smooth muscle & Increased protein \\
\hline CREB & Rat embryo glial cells & Increased binding to $\mathrm{CRE}$ \\
\hline c-myc & Rat vascular smooth muscle & Increased mRNA \\
\hline
\end{tabular}

be activated by ROS by Rac1-transmitted NAD $(\mathrm{P}) \mathrm{H}$ oxidase activation, is linked to endothelial dysfunction and vascular inflammation [108] as well as proliferation in vascular smooth muscle cells, a mechanism critically involved in neo-intima formation. From this it appears that $\mathrm{NF}-\varkappa \mathrm{B}$ is crucially involved in the pathogenesis of atherosclerotic lesions by switching on specific target genes, such as vascular cell adhesion molecules, intercellular adhesion molecules and Eselectin [179]. In bovine endothelial cells hyperglycaemia yielded such activation of NF- $x \mathrm{~B}$ via a PKCdependent mechanism [180]. In the same cell type, AGE products that can initiate oxidative stress [181, 182] activated NF- $x$ B by a mechanism sensitive to alpha-lipoic acid [183]. Increased NF- $x$ B activity seems to be essential for the augmented leucocyte-endothelial interaction during hyperglycaemia [184]. Glycated serum albumin and hyperglycaemia were also found to stimulate NF- $\varkappa \mathrm{B}$ in smooth muscle cells $[185,186]$ and mesangial cells (high D-glucose) [187] by the generation of ROS. Furthermore, the involvement of poly(ADP-ribose) polymerase has been reported in the activation of NF- $x \mathrm{~B}$ by hyperglycaemia [188]. These studies are further supported by the report that insufficient glycaemic control increases $\mathrm{NF}-x \mathrm{~B}$ binding activity in peripheral blood mononuclear cells isolated from patients with Type I (insulindependent) diabetes mellitus [189].
Notably, incubation of HUVECs with high D-glucose increases rapidly the generation of ROS accompanied by NF- $x \mathrm{~B}$ activation, which can be prevented by antioxidants (tocopherol, SOD-mimetic) (Table 3). The formation of ROS was additionally inhibited by the specific eNOS inhibitor L-nitroarginine (L-NNA) [10] and DPI [33], whereas inhibitors of cyclooxygenase and lipoxygenase had no influence [28]. This indicates that high $\mathrm{D}$-glucose leads to an increase in generation of ROS (mainly $\mathrm{O}_{2}^{-}$and $\mathrm{NO}^{\circ}$ [28]) and activates NF- $x \mathrm{~B}$ by a D-glucose specific and eNOS- and PKCdependent mechanism. Hence, Du et al. [178] suggested $\mathrm{ONOO}^{-}$as the mediator of the effects caused by high D-glucose on endothelial cells. Furthermore, $\mathrm{ONOO}^{-}$has been shown to activate NF- $x \mathrm{~B}$ [178].

ROS-mediated changes in the architectural organisation of the cytoskeleton and $\mathrm{Ca}^{2+}$ containing organelles yields marked alterations in cellular $\mathrm{Ca}^{2+}$ homeostasis (see above). This redistribution might largely contribute to the changes in cell function under pathological conditions that accompany increased ROS production. Moreover, changes in subcellular $\mathrm{Ca}^{2+}$ distribution (Fig.3) could reorganise the architecture of the cytoskeleton, modulate $\mathrm{Ca}^{2+}$ sensitive/-activated transcription factors and signal cascade enzymes resulting in altered gene expression [136, 190, 191, 192] (for review see [135]). In line with these data in beta cells, in endothelial cells the 
Table 3. Redox-sensitive Regulatory factors. Effects due to Antioxidants; taken from Allen and Tresini [222]

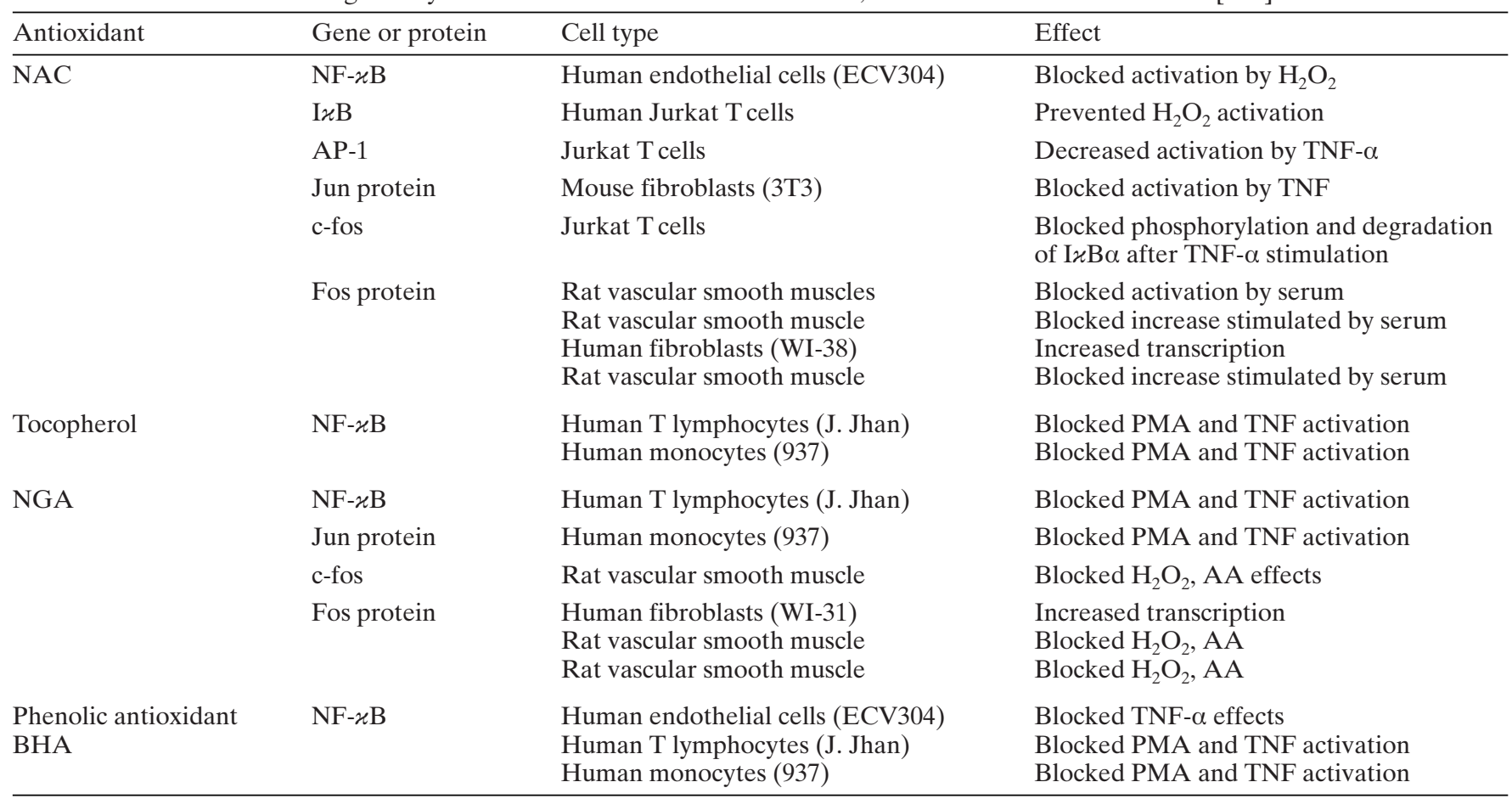

same effects could be observed under diabetic conditions $[28,54,193,194,195,196,197]$. Thereby, the impact of $\mathrm{Ca}^{2+}$ on gene expression exceeded its role in the nuclear envelope, where $\mathrm{Ca}^{2+}$ is essential for modulating immediate early genes by modulating the DNA-binding of transcription factors (e.g. cAMP-responsive element binding protein CREB [191, 192, 198, 199, 200]).

$\mathrm{Ca}^{2+}$ triggers the activation of transcription factors such as the nuclear factor of activated T cells (NFAT) [201, 202, 203, 204, 205, 206] and the serum response factor-related proteins (RSRF or the myocyte enhancer factor 2 (MEF2) [207]) by calcineurin [208] or $\mathrm{Ca}^{2+}$-sensitive kinases (e.g. Cam-kinase IV [207]). In the case of NFAT, the $\mathrm{Ca}^{2+} /$ calmodulin-activated protein phosphatase-2B (calcineurin) dephosphorylates NFAT resulting in its translocation into the nucleus [208] to form a heteromeric transcriptional activator complex with activator-protein-1 (AP-1) and initiates gene expression [202]. In vascular smooth muscle cells NFAT activation by increasing cytosolic free $\mathrm{Ca}^{2+}$ concentration depends on the patterns of the $\mathrm{Ca}^{2+}$ signalling observed in response to the compound tested. Angiotensin II and thrombin, which rapidly but transiently increase $\mathrm{Ca}^{2+}$ concentration, activate NFAT-mediated transcription rather weakly [206]. In contrast, the platelet-derived growth factor $\mathrm{BB}$ (PDGF-BB) yields a higher activity in NFAT-mediated transcription despite the smaller, slower but longer lasting $\mathrm{Ca}^{2+}$ elevation. Thus, depending on the kinetics of bulk $\mathrm{Ca}^{2+}$ increases and that of localised $\mathrm{Ca}^{2+}$ increases, $\mathrm{Ca}^{2+}$ modulates NFAT-mediated gene expression. In endothelial cells, regulation by oscillation frequency of agonist-stimulated NF- $\varkappa \mathrm{B}$ transcriptional activity has been demonstrated [137]. Remarkably, NF-kB transcriptional activity was attenuated by a reduction of the frequency of $\mathrm{Ca}^{2+}$ oscillation at constant amplitude of $\mathrm{Ca}^{2+}$ increases.

Hence, cytosolic $\mathrm{Ca}^{2+}$ stimulates mitogenic signal cascades that induce gene expression (e.g. erk-1/2 [199]; src [116]) and the rearrangement of cytoskeletal proteins ([209], e. g. beta catenin [210, 211], or zyxin [212]). Cytosolic signal cascades might be modulated by the patterns of the cytosolic $\mathrm{Ca}^{2+}$ signalling (e.g. transient or long lasting $\mathrm{Ca}^{2+}$ increases compared to spiking) that, in turn, is controlled by spatial $\mathrm{Ca}^{2+}$ distribution (e.g. subplasmalemmal $\mathrm{Ca}^{2+}[213$, 214, 215, 216, 217]).

Many ROS-sensitive protein kinases (Table 1 Fig. 2) mentioned above further activate or modulate transcription factors as important downstream targets (Table 2; Table 3).

P90RSK that is regulated by its upstream regulator ERK1/2 [218] as well as via Fyn and Ras [116], phosphorylates c-Fos [13], Nur77 [219] and Ik-B, the latter resulting in NF-kB activation [13, 220]. Recently, p90RSK and the closely-related rsk genes have been shown to affect the activity of CREBs [221], while the regulation of AP-1 by ROS involves ERK1/2 and JNK in a cell and stimulus specific manner [13]. 


\section{Conclusion}

The generation of ROS in diabetes mellitus represents a crucial phenomenon that links high D-glucose, AGEs and glycated (lipo-) proteins with particular changes in cell structure and function. In this review we presented some targets of ROS that are rarely discussed and considered in the evaluation of vascular dysfunction in diabetes. That does in no way weaken the importance of other cellular targets of ROS (e.g. PKC, lipids), but might add some new perspectives and targets worthy to be assessed in more detail in diabetes-associated vascular complications. Although there is strong evidence for an activation of NF-kB and AP-1, additional studies will be indispensable to assess the whole range of ROS-activated transcription factors.

Sources. This review is based on the selected literature published in the English language during the last decade. The authors own sources were integrated with sources that resulted from PubMed searches using a search profile containing the words "radicals, peroxide, superoxide anions, oxidative stress" either alone or in conjunction with "diabetes, hyperglycaemia".

Acknowledgements. The authors thank M. Frieden, Department of Physiology, CMU, University of Geneva, Geneva, Switzerland and K. Osibow for their valuable input and considerable help. This work was supported by the Austrian Funds (SFB 714, P-14586-PHA), the Austrian National bank (P7542 and P7902), the Austrian Heart Foundation (OeHF) and the Franz Lanyar Foundation. M. Spitaler is a recipient of the $\mathrm{PhD}$ scholarship of the Austrian Academy of Sciences.

\section{References}

1. Yamagishi SI, Edelstein D, Du XL, Brownlee M (2001) Hyperglycemia potentiates collagen-induced platelet activation through mitochondrial superoxide overproduction. Diabetes 50: 1491-1494

2. Idris I, Gray S, Donnelly R (2001) Protein kinase C activation: isozyme-specific effects on metabolism and cardiovascular complications in diabetes. Diabetologia 44: 659-673

3. Haffner SM (1998) The importance of hyperglycemia in the nonfasting state to the development of cardiovascular disease. Endocr Rev 19: 583-592

4. Uemura S, Matsushita H, Li W et al. (2001) Diabetes mellitus enhances vascular matrix metalloproteinase activity: role of oxidative stress. Circ Res 88: 1291-1298

5. Shimokawa H (1999) Primary endothelial dysfunction: atherosclerosis. J Mol Cell Cardiol 31: 23-37

6. Feron O, Dessy C, Moniotte S, Desager JP, Balligand JL (1999) Hypercholesterolemia decreases nitric oxide production by promoting the interaction of caveolin and endothelial nitric oxide synthase. J Clin Invest 103: 897-905

7. Peterson TE, Poppa V, Ueba H, Wu A, Yan C, Berk BC (1999) Opposing effects of reactive oxygen species and cholesterol on endothelial nitric oxide synthase and endothelial cell caveolae. Circ Res 85: 29-37

8. Cai H, Harrison DG (2000) Endothelial dysfunction in cardiovascular diseases: the role of oxidant stress. Circ Res 87: 840-844

9. Griendling KK, Sorescu D, Ushio-Fukai M (2000) NAD(P)H oxidase: role in cardiovascular biology and disease. Circ Res 86: 494-501

10. Hink U, Li H, Mollnau H et al. (2001) Mechanisms underlying endothelial dysfunction in diabetes mellitus. Circ Res 88: E14-E22

11. Graier WF, Posch K, Fleischhacker E, Wascher TC, Kostner GM (1999) Increased superoxide anion formation in endothelial cells during hyperglycemia: an adaptive response or initial step of vascular dysfunction? Diabetes Res Clin Pract 45: 153-160

12. Lunec J, Winyard P (1998) Reactive oxygen species: Associated pathology. J Int Fed Clin Chem 10: 42-44

13. Abe JI, Berk BC (1998) Reactive Oxygen species as mediators of signal transduction in cardiovascular disease. Trends Cardiovasc Med 8: 59-64

14. Irani K, Goldschmidt-Clermont PJ (1998) Ras, superoxide and signal transduction. Biochem Pharmacol 55:1339-1346

15. O'Donnell VB, Chumley PH, Hogg N, Bloodsworth A, Darley-Usmar VM, Freeman BA (1997) Nitric oxide inhibition of lipid peroxidation: kinetics of reaction with lipid peroxyl radicals and comparison with alpha-tocopherol. Biochemistry 36: 15216-15223

16. Halliwell B, Zhao K, Whiteman M (1999) Nitric oxide and peroxynitrite. The ugly, the uglier and the not so good: a personal view of recent controversies. Free Radic Res 31: 651-669

17. Kunsch C, Medford RM (1999) Oxidative stress as a regulator of gene expression in the vasculature. Circ Res 85: 753-766

18. Kettle AJ, Winterbourn CC (1997) Myeloperoxidase: a key regulator of neutrophile oxiddant production. Redox Rep 3: 3-15

19. Hunt JV, Smith CC, Wolff SP (1990) Autoxidative glycosylation and possible involvement of peroxides and free radicals in LDL modification by glucose. Diabetes 39: 1420-1424

20. Hunt JV, Bottoms MA, Clare K, Skamarauskas JT, Mitchinson MJ (1994) Glucose oxidation and low-density lipoprotein-induced macrophage ceroid accumulation: possible implications for diabetic atherosclerosis. Biochem $\mathrm{J}$ 300: 243-249

21. Qian M, Liu M, Eaton JW (1998) Transition metals bind to glycated proteins forming redox active "glycochelates": implications for the pathogenesis of certain diabetic complications. Biochem Biophys Res Commun 250: 385-389

22. Qian M, Eaton JW (2000) Glycochelates and the etiology of diabetic peripheral neuropathy. Free Radic Biol Med 28: 652-656

23. Dagher MC, Fuchs A, Bourmeyster N, Jouan A, Vignais PV (1995) Small G proteins and the neutrophil NADPH oxidase. Biochimie 77: 651-660

24. Bastian NR, Hibbs JB Jr (1994) Assembly and regulation of NADPH oxidase and nitric oxide synthase. Curr Opin Immunol 6: 131-139

25. DeLeo FR, Quinn MT (1996) Assembly of the phagocyte NADPH oxidase: molecular interaction of oxidase proteins. J Leukoc Biol 60: 677-691

26. Kobayashi T, Seguchi H (1999) Novel insight into current models of NADPH oxidase regulation, assembly and localization in human polymorphonuclear leukocytes. Histol Histopathol 14: 1295-1308 
27. Mazière C, Auclair M, Rose-Robert F, Leflon P, Mazière JC (1995) Glucose-enriched medium enhances cell-mediated low density lipoprotein peroxidation. FEBS Lett 363: $277-279$

28. Graier WF, Simecek S, Kukovetz WR, Kostner GM (1996) High D-glucose-induced changes in endothelial $\mathrm{Ca}^{2+} /$ EDRF signaling are due to generation of superoxide anions. Diabetes 45: 1386-1395

29. Inoguchi T, Li P, Umeda F et al. (2000) High glucose level and free fatty acid stimulate reactive oxygen species production through protein kinase $\mathrm{C}$-dependent activation of NAD(P)H oxidase in cultured vascular cells. Diabetes 49: $1939-1945$

30. Griendling K, Ollerenshaw JD, Minieri CA, Alexander RW (1994) Angiotensin II stimulates NADH and NADPH activity in cultured vascular smooth muscle cells. Circ Res 74: 1141-1148

31. Mohazzab KM, Wolin MS (1994) Sites of superoxide anion production detected by lucigenin in calf pulmonary artery smooth muscle. Am J Physiol 267: L815-L822

32. Mohazzab KM, Kaminski PM, Wolin MS (1994) NADH oxidoreductase is a major source of superoxide anion in bovine coronary artery endothelium. Am J Physiol 266: $\mathrm{H} 2568-\mathrm{H} 2572$

33. Pagano PJ, Ito Y, Tornheim K, Gallop P, Cohen RA (1995) An NADPH oxidase superoxide generating system in the rabbit aorta. Am J Physiol 268: H2274-H2280

34. Guzik TJ, West NE, Black E, McDonald D, Ratnatunga C, Pillai R, Channon KM (2000) Vascular superoxide production by $\mathrm{NAD}(\mathrm{P}) \mathrm{H}$ oxidase: association with endothelial dysfunction and clinical risk factors. Circ Res 86: E85-E90

35. Ishii H, Jirousek MR, Koya D et al. (1996) Amelioration of vascular dysfunctions in diabetic rats by an oral PKC beta inhibitor. Science 272: 728-731

36. Koya D, Haneda M, Nakagawa H et al. (2000) Amelioration of accelerated diabetic mesangial expansion by treatment with a PKCbeta inhibitor in diabetic $\mathrm{db} / \mathrm{db}$ mice, a rodent model for type 2 diabetes. FASEB J 14: 439-447

37. Kuboki K, Jiang ZY, Takahara N et al. (2000) Regulation of endothelial constitutive nitric oxide synthase gene expression in endothelial cells and In vivo : A specific vascular action of insulin. Circulation 101: 676-681

38. Park JY, Takahara N, Gabriele A et al. (2000) Induction of endothelin-1 expression by glucose: an effect of protein kinase C activation. Diabetes 49: 1239-1248

39. Kobayashi T, Robinson JM, Seguchi H (1998) Identification of intracellular sites of superoxide production in stimulated neutrophils. J Cell Sci 111: 81-91

40. Hecker M, Ullrich V (1989) On the mechanism of prostacyclin and thromboxane A2 biosynthesis. J Biol Chem 264: $141-150$

41. Tesfamariam B (1994) Selective impairment of endothelium-dependent relaxations by prostaglandin endoperoxide. J Hypertens 12: 41-47

42. Uriu K, Kaizu K, Hashimoto O, Komine N, Etoh S (1994) Acute and chronic effects of thromboxane A2 inhibition on the renal hemodynamicsin streptozotocin-induced diabetic rats. Kidney Int 45: 794-802

43. De La Cruz JP, Moreno A, Ruiz-Ruiz MI, Garcia Campos J, Sanchez de la Cuesta F (1998) Effect of camonagrel, a selective thromboxane synthase inhibitor, on retinal vascularization in experimental diabetes. Eur J Pharmacol 29: $81-85$

44. De La Cruz JP, Moreno A, Ruiz-Ruiz MI, Sanchez De La Cuesta F (2000) Effect of DT-TX 30, a combined thromboxane synthase inhibitor and thromboxane receptor an- tagonist, on retinal vascularity in experimental diabetes mellitus. Thromb Res 97: 125-131

45. Umeda F, Kuroki T, Nawata H (1995) Prostaglandins and diabetic nephropathy. J Diabetes Complications 9: 334-336

46. Shimizu K, Muramatsu M, Kakegawa Yet al. (1993) Role of prostaglandin $\mathrm{H}_{2}$ as an endothelium-derived contracting factor in diabetic state. Diabetes 42: 1246-1252

47. Tesfamariam B, Jakubowski JA, Cohen RA (1989) Contraction of diabetic rabbit aorta caused by endotheliumderived PGH2-TXA2. Am J Physiol 257: H1327-H1333

48. Tesfamariam B, Brown ML, Deykin D, Cohen RA (1990) Elevated glucose promotes generation of endotheliumderived vasoconstrictor prostanoids in rabbit aorta. J Clin Invest 85: 929-932

49. Terada LS (1996) Hypoxia-reoxygenation increases $\mathrm{O}_{2}{ }^{-}$ efflux which injures endothelial cells by an extracellular mechanism. Am J Physiol 270: H945-H950

50. Nozik-Grayck E, Piantadosi CA, van Adelsberg J, Alper SL, Huang YC (1997) Protection of perfused lung from oxidant injury by inhibitors of anion exchange. Am J Physiol 273: H296-H304

51. Cohen R (1993) Dysfunction of vascular endothelium in diabetes mellitus. Circulation 87 [Suppl V]: V67-V76

52. Tesfamariam B, Cohen RA (1992) Free radicals mediate endothelial cell dysfunction caused by elevated glucose. Am J Physiol 263: H321-H326

53. Pieper GM (1998) Review of alterations in endothelial nitric oxide production in diabetes: protective role of arginine on endothelial dysfunction. Hypertension 31: 1047-1060

54. Graier WF, Simecek S, Hoebel BG, Wascher TC, Dittrich P, Kostner GM (1997) Antioxidants prevent high D-glucose-enhanced endothelial $\mathrm{Ca}^{2+} / \mathrm{cGMP}$ response by scavanging superoxide anions. Eur J Pharmacol 322: 113-122

55. Ammar RF Jr, Gutterman DD, Brooks LA, Dellsperger KC (2000) Free radicals mediate endothelial dysfunction of coronary arterioles in diabetes. Cardiovasc Res 47: 595-601

56. Pieper GM, Langenstroer P, Siebeneich W (1997) Diabetic-induced endothelial dysfunction in rat aorta: role of hydroxyl radicals. Cardiovasc Res 34: 145-156

57. Ceriello A, dello Russo P, Amstad P, Cerutti P (1996) High glucose induces antioxidant enzymes in human endothelial cells in culture. Evidence linking hyperglycemia and oxidative stress. Diabetes 45: 471-477

58. Kakkar R, Mantha SV, Kalra J, Prasad K (1996) Time course study of oxidative stress in aorta and heart of diabetic rat. Clin Sci (Colch) 91: 441-448

59. Kobayashi T, Kamata K (1999) Relationship among cholesterol, superoxide anion and endothelium-dependent relaxation in diabetic rats. Eur J Pharmacol 367: 213-222

60. Kamata K, Kobayashi T (1996) Changes in superoxide dismutase mRNA expression by streptozotocin-induced diabetes. Br J Pharmacol 119: 583-589

61. Zanetti M, Sato J, Katusic ZS, O'Brien T (2001) Gene transfer of superoxide dismutase isoforms reverses endothelial dysfunction in diabetic rabbit aorta. Am J Physiol 280: $\mathrm{H} 2516-\mathrm{H} 2523$

62. Kimura C, Oike M, Koyama T, Ito Y (2001) Impairment of endothelial nitric oxide production by acute glucose overload. Am J Physiol Endocrinol Metab 280: E171-E178

63. Wang HD, Pagano PJ, Du Y et al. (1998) Superoxide anion from the adventitia of the rat thoracic aorta inactivates nitric oxide. Circ Res 82: 810-818 
64. Cosentino F, Hishikawa K, Katusic ZS, Lüscher TF (1997) High glucose increases nitric oxide synthase expression and superoxide anion generation in human aortic endothelial cells. Circulation 96: 28-28

65. Perreault M, Dombrowski L, Marette A (2000) Mechanism of impaired nitric oxide synthase activity in skeletal muscle of streptozotocin-induced diabetic rats. Diabetologia 43: 427-437

66. Stockklauser-Farber K, Ballhausen T, Laufer A, Rosen P (2000) Influence of diabetes on cardiac nitric oxide synthase expression and activity. Biochim Biophys Acta 1535: 10-20

67. Felaco M, Grilli A, De Lutiis MA et al. (2001) Endothelial nitric oxide synthase (eNOS) expression and localization in healthy and diabetic rat hearts. Ann Clin Lab Sci 31: 179-186

68. Wu G, Meininger CJ (1995) Impaired arginine metabolism and NO synthesis in coronary endothelial cells of the spontaneously diabetic BB rat. Am J Physiol 269: H1312-H1318

69. Pieper GM, Siebeneich W, Moore-Hilton G, Roza AM (1997) Reversal by L-arginine of a dysfunctional arginine/nitric oxide pathway in the endothelium of the genetic diabetic BB rat. Diabetologia 40: 910-915

70. Pieper GM (1997) Acute amelioration of diabetic endothelial dysfunction with a derivative of the nitric oxide synthase cofactor, tetrahydrobiopterin. J Cardiovasc Pharmacol 29: 8-15

71. Du XL, Edelstein D, Dimmeler S, Ju Q, Sui C, Brownlee M (2001) Hyperglycemia inhibits endothelial nitric oxide synthase activity by posttranslational modification at the Akt site. J Clin Invest 108: 1341-1348

72. Meininger CJ, Marinos RS, Hatakeyama K et al. (2000) Impaired nitric oxide production in coronary endothelial cells of the spontaneously diabetic BB rat is due to tetrahydrobiopterin deficiency. Biochem J 349: 353-356

73. Pou S, Pou WS, Bredt DS, Snyder SH, Rosen GM (1992) Generation of superoxide by purified brain nitric oxide synthase. J Biol Chem 267: 24173-24176

74. Vasquez-Vivar J, Kalyanaraman B, Martasek P et al. (1998) Superoxide generation by endothelial nitric oxide synthase: the influence of cofactors. Proc Natl Acad Sci U S A 95: 9220-9225

75. Xia Y, Tsai AL, Berka V, Zweier JL (1998) Superoxide generation from endothelial nitric-oxide synthase. A $\mathrm{Ca}^{2+} /$ calmodulin-dependent and tetrahydrobiopterin regulatory process. J Biol Chem 273: 25804-25808

76. Laursen JB, Somers M, Kurz S et al. (2001) Endothelial regulation of vasomotion in apoE-deficient mice: implications for interactions between peroxynitrite and tetrahydrobiopterin. Circulation 103: 1282-1288

77. Ishii H, Koya D, King GL (1998) Protein kinase C activation and its role in the development of vascular complications in diabetes mellitus. J Mol Med 76: 21-31

78. Nishikawa T, Edelstein D, Du XL et al. (2000) Normalizing mitochondrial superoxide production blocks three pathways of hyperglycaemic damage. Nature 404: 787-790

79. Nishikawa T, Edelstein D, Brownlee M (2000) The missing link: A single inifying mechanism for diabetic complication. Kidney Int 58 [Suppl 77]: 26-30

80. Wilcox JN, Subramanian RR, Sundell CL et al. (1997) Expression of multiple isoforms of nitric oxide synthase in normal and atherosclerotic vessels. Arterioscler Thromb Vasc Biol 17: 2479-2488

81. Rosen P, Ballhausen T, Stockklauser K (1996) Impairment of endothelium dependent relaxation in the diabetic rat heart: mechanisms and implications. Diabetes Res Clin Pract 31 [Suppl]: S143-S155

82. Kobayashi T, Kamata K (2001) Effect of chronic insulin treatment on NO production and endothelium-dependent relaxation in aortae from established STZ-induced diabetic rats. Atherosclerosis 155: 313-320

83. Shimokawa H, Flavahan NA, Vanhoutte PM (1991) Loss of endothelial pertussis toxin-sensitive $G$ protein function in atherosclerotic porcine coronary arteries. Circulation 83: 652-660

84. Williamson JR, Chang K, Frangos M et al. (1993) Hyperglycemic pseudohypoxia and diabetic complications. Diabetes 42: 801-813

85. Tesfamariam B, Brown ML, Cohen RA (1992) Aldose reductase and myo-inositol in endothelial cell dysfunction caused by elevated glucose. J Pharmacol Exp Ther 263: $153-157$

86. Tesfamariam B, Palacino JJ, Weisbrod RM, Cohen RA (1993) Aldose reductase inhibition restores endothelial cell function in diabetic rabbit aorta. J Cardiovasc Pharmacol 21: 205-211

87. Du XL, Edelstein D, Rossetti L et al. (2000) Hyperglycemia-induced mitochondrial superoxide overproduction activates the hexosamine pathway and induces plasminogen activator inhibitor-1 expression by increasing Sp1 glycosylation. Proc Natl Acad Sci U S A 97: 12222-12226

88. Ide T, Tsutsui H, Kinugawa S et al. (1999) Mitochondrial electron transport complex I is a potential source of oxygen free radicals in the failing myocardium. Circ Res 85: $357-633$

89. Ide T, Tsutsui H, Kinugawa S et al. (2000) Direct evidence for increased hydroxyl radicals originating from superoxide in the failing myocardium. Circ Res 86: 152-157

90. Ballinger SW, Patterson C, Yan CN et al. (2000) Hydrogen peroxide- and peroxynitrite-induced mitochondrial DNA damage and dysfunction in vascular endothelial and smooth muscle cells. Circ Res 86: 960-966

91. Hall A (1998) Rho GTPases and the actin cytoskeleton. Science 279: 509-514

92. Vojtek AB, Der CJ (1998) Increasing complexity of the Ras signaling pathway. J Biol Chem 273: 19925-19928

93. Barry ST, Critchley DR (1994) The RhoA-dependent assembly of focal adhesions in Swiss 3 T3 cells is associated with increased tyrosine phosphorylation and the recruitment of both pp125FAK and protein kinase C-delta to focal adhesions. J Cell Sci 107: 2033-2045

94. Allen WE, Jones GE, Pollard JW, Ridley AJ (1997) Rho, Rac and Cdc42 regulate actin organization and cell adhesion in macrophages. J Cell Sci 110: 707-720

95. Pruefer D, Scalia R, Lefer AM (1999) Simvastatin inhibits leukocyte-endothelial cell interactions and protects against inflammatory processes in normocholesterolemic rats. Arterioscler Thromb Vasc Biol 19: 2894-2900

96. Sundaresan M, Yu ZX, Ferrans VJ et al. (1996) Regulation of reactive-oxygen-species generation in fibroblasts by Rac1. Biochem J 318: 379-382

97. Irani K, Xia Y, Zweier JL et al. (1997) Mitogenic signaling mediated by oxidants in Ras-transformed fibroblasts. Science 275: 1649-1651

98. Pai EF, Krengel U, Petsko GA, Goody RS, Kabsch W, Wittinghofer A (1990) Refined crystal structure of the triphosphate conformation of H-ras p21 at 1.35 A resolution: implications for the mechanism of GTP hydrolysis. EMBO J 9: 2351-2359

99. Rajagopalan S, Kurz S, Munzel T et al. (1996) Angiotensin II-mediated hypertension in the rat increases vascular superoxide production via membrane NADH/NADPH 
oxidase activation. Contribution to alterations of vasomotor tone. J Clin Invest 97: 1916-1923

100. Hancock JF, Magee AI, Childs JE, Marshall CJ (1989) All ras proteins are polyisoprenylated but only some are palmitoylated. Cell 57: 1167-1177

101. Wagner AH, Kohler T, Ruckschloss U, Just I, Hecker M (2000) Improvement of nitric oxide-dependent vasodilatation by $\mathrm{HMG}-\mathrm{CoA}$ reductase inhibitors through attenuation of endothelial superoxide anion formation. Arterioscler Thromb Vasc Biol 20: 61-69

102. Laufs U, Liao JK (2000) Targeting Rho in cardiovascular disease. Circ Res 87: 526-528

103. Hernandez-Perera O, Perez-Sala D, Soria E, Lamas S (2000) Involvement of Rho GTPases in the transcriptional inhibition of preproendothelin-1 gene expression by simvastatin in vascular endothelial cells. Circ Res 87: 616-622

104. Laufs U, Liao JK (1998) Post-transcriptional regulation of endothelial nitric oxide synthase mRNA stability by Rho GTPase. J Biol Chem 273: 24266-24271

105. Crawford LE, Milliken EE, Irani K et al. (1996) Superoxide-mediated actin response in post-hypoxic endothelial cells. J Biol Chem 271: 26863-26867

106. Moldovan L, Irani K, Moldovan NI, Finkel T, Goldschmidt-Clermont PJ (1999) The actin cytoskeleton reorganization induced by Rac1 requires the production of superoxide. Antioxid Redox Signal 1: 29-43

107. Laufs U, Endres M, Stagliano N et al. (2000) Neuroprotection mediated by changes in the endothelial actin cytoskeleton. J Clin Invest 106: 15-24

108. Irani K (2000) Oxidant signaling in vascular cell growth, death, and survival : a review of the roles of reactive oxygen species in smooth muscle and endothelial cell mitogenic and apoptotic signaling. Circ Res 87: 179-183

109. Abe MK, Kartha S, Karpova AY et al. (1998) Hydrogen peroxide activates extracellular signal-regulated kinase via protein kinase C, Raf-1, and MEK1. Am J Respir Cell Mol Biol 18: 562-569

110. Guyton KZ, Liu Y, Gorospe M, Xu Q, Holbrook NJ (1996) Activation of mitogen-activated protein kinase by $\mathrm{H} 2 \mathrm{O} 2$. Role in cell survival following oxidant injury. J Biol Chem 271: 4138-4142

111. Schaffler A, Arndt H, Scholmerich J, Palitzsch KD (2000) Amelioration of hyperglycemic and hyperosmotic induced vascular dysfunction by in vivo inhibition of protein kinase $\mathrm{C}$ and $\mathrm{p} 38$ MAP kinase pathway in the rat mesenteric microcirculation. Eur J Clin Invest 30: 586-593

112. Abe J, Kusuhara M, Ulevitch RJ, Berk BC, Lee JD (1996) Big mitogen-activated protein kinase 1 (BMK1) is a redox-sensitive kinase. J Biol Chem 271: 16586-16590

113. Kyriakis JM, Avruch J (1996) Sounding the alarm: protein kinase cascades activated by stress and inflammation. J Biol Chem 271: 24313-24316

114. Downward J (1998) Mechanisms and consequences of activation of protein kinase B/Akt. Curr Opin Cell Biol 10: 262-267

115. Ushio-Fukai M, Alexander RW, Akers M et al. (1999) Reactive oxygen species mediate the activation of Akt/protein kinase B by angiotensin II in vascular smooth muscle cells. J Biol Chem 274: 22699-22704

116. Abe J, Okuda M, Huang Q, Yoshizumi M, Berk BC (2000) Reactive Oxygen Species Activate p90 Ribosomal S6 Kinase via Fyn and Ras. J Biol Chem 275: 1739-1748

117. Griendling KK, Sorescu D, Lassegue B, Ushio-Fukai M (2000) Modulation of protein kinase activity and gene expression by reactive oxygen species and their role in vascular physiology and pathophysiology. Arterioscler Thromb Vasc Biol 20: 2175-2183
118. Frank GD, Motley ED, Inagami T, Eguchi S (2000) $\mathrm{PYK}_{2} /$ CAKbeta represents a redox-sensitive tyrosine kinase in vascular smooth muscle cells. Biochem Biophys Res Commun 270: 761-765

119. Gozin A, Franzini E, Andrieu V, Da Costa L, Rollet-Labelle E, Pasquier C (1998) Reactive oxygen species activate focal adhesion kinase, paxillin and p130cas tyrosine phosphorylation in endothelial cells. Free Radic Biol Med 25: 1021-1032

120. Exner M, Hermann M, Hofbauer R et al. (2001) Genistein prevents the glucose autoxidation mediated atherogenic modification of low density lipoprotein. Free Radic Res 34: 101-112

121. Nagase H, Woessner JF Jr (1999) Matrix metalloproteinases. J Biol Chem 274: 21491-21494

122. Hanemaaijer R, Koolwijk P, le Clercq L, de Vree WJ, van Hinsbergh VW (1993) Regulation of matrix metalloproteinase expression in human vein and microvascular endothelial cells. Effects of tumour necrosis factor alpha, interleukin 1 and phorbol ester. Biochem J 296: 803-809

123. Sato H, Kita M, Seiki M (1993) v-Src activates the expression of 92-kDa type IV collagenase gene through the AP1 site and the GT box homologous to retinoblastoma control elements. A mechanism regulating gene expression independent of that by inflammatory cytokines. J Biol Chem 268: 23460-23468

124. Li N, Karin M (1999) Is NF-kappaB the sensor of oxidative stress? FASEB J 13: 1137-1143

125. Rajagopalan S, Meng XP, Ramasamy S, Harrison DG, Galis ZS (1996) Reactive oxygen species produced by macrophage-derived foam cells regulate the activity of vascular matrix metalloproteinases in vitro. Implications for atherosclerotic plaque stability. J Clin Invest 98: 2572-2579

126. Galis ZS, Sukhova GK, Lark MW, Libby P (1994) Increased expression of matrix metalloproteinases and matrix degrading activity in vulnerable regions of human atherosclerotic plaques. J Clin Invest 94: 2493-2503

127. Dollery CM, McEwan JR, Henney AM (1995) Matrix metalloproteinases and cardiovascular disease. Circ Res 77: 863-868

128. Kai H, Ikeda H, Yasukawa H et al. (1998) Peripheral blood levels of matrix metalloproteases-2 and -9 are elevated in patients with acute coronary syndromes. J Am Coll Cardiol 32: 368-372

129. Moulton KS, Heller E, Konerding MA, Flynn E, Palinski W, Folkman J (1999) Angiogenesis inhibitors endostatin or TNP-470 reduce intimal neovascularization and plaque growth in apolipoprotein E-deficient mice. Circulation 99: $1726-1732$

130. Werb Z, Tremble PM, Behrendtsen O, Crowley E, Damsky CH (1989) Signal transduction through the fibronectin receptor induces collagenase and stromelysin gene expression. J Cell Biol 109: 877-889

131. Kheradmand F, Werner E, Tremble P, Symons M, Werb Z (1998) Role of Rac1 and oxygen radicals in collagenase-1 expression induced by cell shape change. Science 280: 898-902

132. Paltauf-Doburzynska J, Posch K, Paltauf G, Graier WF (1998) Stealth ryanodine-sensitive $\mathrm{Ca}^{2+}$ release contributes to activity of capacitative $\mathrm{Ca}^{2+}$ entry and nitric oxide synthase in bovine endothelial cells. J Physiol (Lond) 513: 369-379

133. Paltauf-Doburzynska J, Frieden M, Spitaler M, Graier WF (2000) Histamine-induced $\mathrm{Ca}^{2+}$ oscillations in a human endothelial cell line depend on transmembrane ion flux, ryanodine receptors and endoplasmic reticulum $\mathrm{Ca}^{2+}$-ATPase. J Physiol (Lond) 524: 701-713 
134. Hardingham GE, Chawla S, Johnson CM, Bading H (1997) Distinct functions of nuclear and cytoplasmic calcium in the control of gene expression. Nature 385: 260-265

135. Hardingham GE, Bading H (1999) Calcium as a versatile second messenger in the control of gene expression. Microsc Res Tech 46: 348-355

136. Dolmetsch RE, Xu K, Lewis RS (1998) Calcium oscillations increase the efficiency and specificity of gene expression. Nature 392: 933-936

137. Hu Q, Deshpande S, Irani K, Ziegelstein RC (1999) $\left[\mathrm{Ca}^{2+}\right]_{\mathrm{i}}$ oscillation frequency regulates agonist-stimulated NF-kappaB transcriptional activity. J Biol Chem 274: 33995-33998

138. Sobey CG (2001) Potassium channel function in vascular disease. Arteriosler Thromb Vasc Biol 21: 28-38

139. Graier WF, Sturek M, Kukovetz WR (1994) $\mathrm{Ca}^{2+}$ regulation and endothelial vascular function. Endothelium 1: 223-236

140. Edwards G, Dora KA, Gardener MJ, Garland CJ, Weston $\mathrm{AH}(1998) \mathrm{K}^{+}$is an endothelium-derived hyperpolarizing factor in rat arteries. Nature 396: 269-272

141. Fukao M, Hattori Y, Kanno M, Sakuma I, Kitabatake A (1997) Alterations in endothelium-dependent hyperpolarization and relaxation in mesenteric arteries from streptozotocin-induced diabetic rats. $\mathrm{Br} \mathrm{J}$ Pharmacol 121: 1383-1391

142. Wigg SJ, Tare M, Tonta MA, O'Brien RC, Meredith IT, Parkington HC (2001) Comparison of effects of diabetes mellitus on an EDHF-dependent and an EDHF-independent artery. Am J Physiol 281: H232-H240

143. Mayhan WG, Faraci FM (1993) Responses of cerebral arterioles in diabetic rats to activation of ATP-sensitive potassium channels. Am J Physiol 265: H152-H157

144. Zimmermann PA, Knot HJ, Stevenson AS, Nelson MT (1997) Increased myogenic tone and diminished responsiveness to ATP-sensitive $\mathrm{K}^{+}$channel openers in cerebral arteries from diabetic rats. Circ Res 81: 996-1004

145. Wesson DE, Elliott SJ (1994) Xanthine oxidase inhibits transmembrane signal transduction in vascular endothelial cells. J Pharmacol Exp Ther 270: 1197-1207

146. Graier WF, Hoebel BG, Paltauf DJ, Kostner GM (1998) Effects of superoxide anions on endothelial $\mathrm{Ca}^{2+}$ signaling pathways. Arterioscler Thromb Vasc Biol 18: 1470-1479

147. Kimura C, Oike M, Ito Y (1998) Acute glucose overload abolishes $\mathrm{Ca}^{2+}$ oscillation in cultured endothelial cells from bovine aorta: a possible role of superoxide anion. Circ Res 82: 677-685

148. Kamata K, Sugiura M, Kasuya Y (1995) Decreased $\mathrm{Ca}^{2+}$ influx into the endothelium contributes to the decrease in endothelium-dependent relaxation in the aorta of streptozotocin-induced diabetic mice. Res Commun Mol Pathol Pharmacol 90: 69-74

149. Kamata K, Nakajima M (1998) $\mathrm{Ca}^{2+}$ mobilization in the aortic endothelium in streptozotocin-induced diabetic and cholesterol-fed mice. Br J Pharmacol 123: 1509-1516

150. Smogorzewski M, Galfayan V, Massry SG (1998) High glucose concentration causes a rise in $\left[\mathrm{Ca}^{2+}\right]_{i}$ of cardiac myocytes. Kidney Int 53: 1237-1243

151. Wang DW, Kiyosue T, Shigematsu S, Arita M (1995) Abnormalities of $\mathrm{K}^{+}$and $\mathrm{Ca}^{2+}$ currents in ventricular myocytes from rats with chronic diabetes. Am J Physiol 269: H1288-H1296

152. Koliwad SK, Kunze DL, Elliott SJ (996) Oxidant stress activates a non-selective cation channel responsible for membrane depolarization in calf vascular endothelial cells. J Physiol (Lond) 1-12
153. Balzer M, Lintschinger B, Groschner K (1999) Evidence for a role of Trp proteins in the oxidative stress-induced membrane conductances of porcine aortic endothelial cells. Cardiovasc Res 42: 543-549

154. Jabr RI, Cole WC (1995) Oxygen-derived free radical stress activates nonselective cation current in guinea pig ventricular myocytes. Role of sulfhydryl groups. Circ Res 76: $812-824$

155. Cai S, Sauve R (1997) Effects of thiol-modifying agents on a $\mathrm{K}_{\mathrm{Ca}}{ }^{2+}$ channel of intermediate conductance in bovine aortic endothelial cells. J Memb Biol 158: 147-158

156. Sohn HY, Keller M, Gloe T, Morawietz H, Rueckschloss U, Pohl U (2000) The small G-protein Rac mediates depolarization-induced superoxide formation in human endothelial cells. J Biol Chem 275: 18745-18750

157. Elliott SJ (1996) Peroxynitrite modulates receptor-activated $\mathrm{Ca}^{2+}$ signaling in vascular endothelial cells. Am J Physiol 270: L954-L961

158. Brzezinska AK, Gebremedhin D, Chilian WM, Kalyanaraman B, Elliott SJ (2000) Peroxynitrite reversibly inhibits $\mathrm{Ca}^{2+}$-activated $\mathrm{K}^{+}$channels in rat cerebral artery smooth muscle cells. Am J Physiol 278: H1883-H1890

159. Lückhoff A, Pohl U, Mülsch A, Busse R (1988) Differential role of extra- and intracellular calcium in the release of EDRF and prostacyclin from cultured endothelial cells. Br J Pharmacol 95: 189-196

160. Groschner K, Graier WF, Kukovetz WR (1992) Activation of a small-conductance $\mathrm{Ca}^{2+}$-dependent $\mathrm{K}^{+}$channel contributes to bradykinin-induced stimulation of nitric oxide synthesis in pig aortic endothelial cells. Biochim Biophys Acta 1137: 162-170

161. Suzuki YJ, Ford GD (1991) Inhibition of $\mathrm{Ca}^{2+}$-ATPase of vascular smooth muscle sarcoplasmic reticulum by reactive oxygen intermediates. Am J Physiol 261: H568-H574

162. Suzuki YJ, Ford GD (1992) Superoxide stimulates IP3-induced $\mathrm{Ca}^{2+}$ release from vascular smooth muscle sarcoplasmic reticulum. Am J Physiol 262: H114-H146

163. Kawakami M, Okabe E (1998) Superoxide anion radicaltriggered $\mathrm{Ca}^{2+}$ release from cardiac sarcoplasmic reticulum through ryanodine receptor $\mathrm{Ca}^{2+}$ channel. Mol Pharmacol 53: 497-503

164. Favero TG, Zable AC, Abramson JJ (1995) Hydrogen peroxide stimulates the $\mathrm{Ca}^{2+}$ release channel from skeletal muscle sarcoplasmic reticulum. J Biol Chem 270: 25557-25563

165. Anzai K, Ogawa K, Kuniyasu A, Ozawa T, Yamamoto H, Nakayama H (1998) Effects of hydroxyl radical and sulfhydryl reagents on the open probability of the purified cardiac ryanodine receptor channel incorporated into planar lipid bilayers. Biochem Biophys Res Commun 249: 938-942

166. Reichman N, Porteous CM, Murphy MP (1994) Cyclosporin A blocks 6-hydroxydopamine-induced efflux of $\mathrm{Ca}^{2+}$ from mitochondria without inactivating the mitochondrial inner-membrane pore. Biochem J 297: 151-155

167. Crompton M, Costi A (1990) A heart mitochondrial $\mathrm{Ca}^{2+}$ dependent pore of possible relevance to re-perfusion-induced injury. Evidence that ADP facilitates pore interconversion between the closed and open states. Biochem J 266: 33-39

168. Jornot L, Maechler P, Wollheim CB, Junod AF (1999) Reactive oxygen metabolites increase mitochondrial calcium in endothelial cells: implication of the $\mathrm{Ca}^{2+} / \mathrm{Na}^{+}$exchanger. J Cell Sci 112: 1013-1022

169. Schaeffer G, Wascher TC, Kostner GM, Graier WF (1999) Alterations in platelet $\mathrm{Ca}^{2+}$ signalling in diabetic patients is due to increased formation of superoxide an- 
ions and reduced nitric oxide production. Diabetologia 42: 167-176

170. Weisbrod RM, Griswold MC, Du Y, Bolotina VM, Cohen RA (1997) Reduced responsiveness of hypercholesterolemic rabbit aortic smooth muscle cells to nitric oxide. Arterioscler Thromb Vasc Biol. 17: 394-402

171. Del Rio M, Chulia T, Ruiz E, Tejerina T (1996) Action of probucol in arteries from normal and hypercholesterolemic rabbits. Br J Pharmacol 118: 1639-1644

172. Yoo HJ, Kozaki K, Akishita M et al. (1997) Aumented $\mathrm{Ca}^{2+}$ influx is involved in the mechanism of enhanced proliferation of cultured vascular smooth muscle cells from spotaneously diabetic Goto-Kakizaki rats. Atherosclerosis 131: 167-175

173. Tam ESL, Ferguson DG, Bielefeld DR, Lorenz JN, Cohen RM, Pun RYK (1997) Norepinephrine-mediated calcium signaling is altered in vascular smooth muscle of diabetic rat. Cell Calcium 21: 143-150

174. Fleischhacker E, Esenabhalu VE, Spitaler M et al. (1999) Human diabetes is associated with hyperreactivity of vascular smooth muscle cells due to altered subcellular $\mathrm{Ca}^{2+}$ distribution. Diabetes 48: 1323-1330

175. Barbagallo M, Shan J, Pang PK, Resnick, LM (1995) Glucose-induced alterations of cytosolic free calcium in cultured rat tail artery vascular smooth muscle cells. J Clin Invest 95: 763-767

176. Pieper GM, Siebeneich W, Roza AM, Jordan M, Adams MB (1996) Chronic treatment in vivo with dimethylthiourea, a hydroxyl radical scavenger, prevents diabetesinduced endothelial dysfunction. J Cardiovasc Pharmacol 28: 741-745

177. Samad F, Loskutoff DJ (1999) Hemostatic gene expression and vascular disease in obesity: insights from studies of genetically obese mice. Thromb Haemost 82: 742-747

178. Du X, Stocklauser-Farber K, Rosen P (1999) Generation of reactive oxygen intermediates, activation of NF-kap$\mathrm{paB}$, and induction of apoptosis in human endothelial cells by glucose: role of nitric oxide synthase? Free Radic Biol Med 27: 752-763

179. Golovchenko I, Goalstone ML, Watson P, Brownlee M, Draznin B (2000) Hyperinsulinemia enhances transcriptional activity of nuclear factor-kappaB induced by angiotensin II, hyperglycemia, and advanced glycosylation end products in vascular smooth muscle cells. Circ Res 87: 746-752

180. Pieper GM, Riaz ul H (1997) Activation of nuclear factorkappaB in cultured endothelial cells by increased glucose concentration: prevention by calphostin C. J Cardiovasc Pharmacol 30: 528-532

181. Wautier JL, Wautier MP, Schmidt AM et al. (1994) Advanced glycation end products (AGEs) on the surface of diabetic erythrocytes bind to the vessel wall via a specific receptor inducing oxidant stress in the vasculature: a link between surface-associated AGEs and diabetic complications. Proc Natl Acad Sci U S A 91: 7742-7746

182. Schmidt AM, Hori O, Chen JX et al. (1995) Advanced glycation endproducts interacting with their endothelial receptor induce expression of vascular cell adhesion molecule-1 (VCAM-1) in cultured human endothelial cells and in mice. A potential mechanism for the accelerated vasculopathy of diabetes. J Clin Invest 96: 1395-1403

183. Bierhaus A, Chevion S, Chevion M et al. (1997) Advanced glycation end product-induced activation of NFkappaB is suppressed by alpha-lipoic acid in cultured endothelial cells. Diabetes 46: 1481-1490

184. Morigi M, Angioletti S, Imberti B et al. (1998) Leukocyteendothelial interaction is augmented by high glucose con- centrations and hyperglycemia in a NF-kB-dependent fashion. J Clin Invest 101: 1905-1915

185. Hattori Y, Banba N, Gross SS, Kasai K (1999) Glycated serum albumin-induced nitric oxide production in vascular smooth muscle cells by nuclear factor kappaB-dependent transcriptional activation of inducible nitric oxide synthase. Biochem Biophys Res Commun 259: 128-132

186. Yerneni KK, Bai W, Khan BV, Medford RM, Natarajan R (1999) Hyperglycemia-induced activation of nuclear transcription factor kappaB in vascular smooth muscle cells. Diabetes 48: 855-864

187. Ha H, Lee HB (2000) Reactive oxygen species as glucose signaling molecules in mesangial cells cultured under high glucose. Kidney Int [Suppl 77[: S19-S25

188. Garcia Soriano F, Virag L, Jagtap P et al. (2001) Diabetic endothelial dysfunction: the role of poly(ADP-ribose) polymerase activation. Nat Med 7: 108-113

189. Hofmann MA, Schiekofer S, Kanitz M et al. (1998) Insufficient glycemic control increases nuclear factor-kappa B binding activity in peripheral blood mononuclear cells isolated from patients with type 1 diabetes. Diabetes Care 21: $1310-1316$

190. Dolmetsch RE, Lewis RS (1994) Signaling between intracellular $\mathrm{Ca}^{2+}$ stores and depletion-activated $\mathrm{Ca}^{2+}$ channels generates $\left[\mathrm{Ca}^{2+}\right]$ i oscillations in T lymphocytes. J Gen Physiol 103: 365-388

191. Thorn P, Lawrie AM, Smith PM, Gallacher DV, Petersen $\mathrm{OH}$ (1993) $\mathrm{Ca}^{2+}$ oscillations in pancreatic acinar cells: spatiotemporal relationships and functional implications. Cell Calcium 14: 746-757

192. Thorn P, Lawrie AM, Smith PM, Gallacher DV, Petersen $\mathrm{OH}$ (1993) Local and global cytosolic $\mathrm{Ca}^{2+}$ oscillations in exocrine cells evoked by agonist and inositol trisphosphate. Cell 74: 661-668

193. Graier WF, Wascher TC, Lackner L, Toplak H, Krejs GJ, Kukovetz WR (1993) Exposure to elevated D-glucose concentrations modulates vascular endothelial cell vasodilatatory response. Diabetes 42: 1497-1505

194. Graier WF, Posch K, Wascher TC, Kostner GM (1997) Role of superoxide anions in changes of endothelial vasoactive response duringacute hyperglycemia. Horm Metab Res 29: 622-626

195. Baumgartner-Parzer S, Wagner O, Nowotny P, Vierhapper H, Waldhäusl W (1994) Stimulation of endothelin-1 production by thrombin, but lack of interference by high ambient glucose in vitro. Eur J Endocrinol 130: 271-275

196. Baumgartner-Parzer S, Wagner L, Pettermann M, Gessl A, Waldhäusl W (1995) Modulation by high glucose of adhesion molecule expression. Diabetologia 38: 1367-1370

197. Baumgartner-Parzer SM, Wagner L, Pettermann M, Grillari J, Gessl A, Waldhäusl W (1995) High-glucose-triggered apoptosis in cultured endothelial cells. Diabetes 44: $1323-1327$

198. Malviya AN, Rogue PJ (1998) "Tell me where is calcium bred": Clarifying the roles of nuclear calcium. Cell 92:17-23

199. English J, Pearson G, Wilsbacher J et al. (1999) New insights into the control of map kinase pathways. Exp Cell Res 253: 255-270

200. Ferrier J, Yu H (1996) Nuclear versus perinuclear and cytoplasmic calcium in osteoclasts. Cell Calcium 20: 381-388

201. Clipstone NA, Crabtree GR (1992) Identification of calcineurin as a key signalling enzyme in T-lymphocyte activation. Nature 357: 695-697

202. Jain J, McCaffrey PG, Valge-Archer VE, Rao A (1992) Nuclear factor of activated T cells contains Fos and Jun. Nature 356: 801-804 
203. Jain J, Miner Z, Rao A (1993) Analysis of the preexisting and nuclear forms of nuclear factor of activated T cells. J Immunol 151: 837-848

204. Loh C, Shaw KT, Carew J et al. (1996) Calcineurin binds the transcription factor NFAT1 and reversibly regulates its activity. J Biol Chem 271: 10884-10891

205. Shaw KT, Ho AM, Raghavan A et al. (1995) Immunosuppressive drugs prevent a rapid dephosphorylation of transcription factorNFAT1 in stimulated immune cells. Proc Natl Acad Sci USA 92: 11205-11209

206. Boss V, Abbott KS, Wang XF, Pavlath GK, Murphy TJ (1998) The cyclosporin A-sensitive nucear factor of activated T cells (NFAT) proteins are expressed in vascular smooth muscle cells. J Biol Chem 273: 19664-19671

207. Blaeser F, Ho N, Prywes R, Chatila TA (2000) $\mathrm{Ca}^{2+}$-dependent gene expression mediated by MEF2 transcription factors. J Biol Chem 275: 197-209

208. Scott JE, Ruff VA, Leach KL (1997) Dynamic equilibrium between calcineurin and kinase activities regulates the phosphorylation state and localization of the nuclear factor of activated T-cells. Biochem J 324: 597-603

209. Kraus M, Wolf B, Wolf B (1996) Crosstalk between cellular morphology and calcium oscillation patterns. Insights from a stochastic computer model. Cell Calcium 19: 461-472

210. Ito K, Okamoto I, Araki N et al. (1999) Calcium influx triggers the sequential proteolysis of extracellular and cytoplasmic domains of E-cadherin, leading to loss of beta-catenin from cell-cell contacts. Oncogene 25: 7080-7090

211. Ayalon O, Geiger B (1997) Cyclic changes in the organization of cell adhesions and the associated cytosceleton, induced by stimulation of tyrosine phosphorylation in bovine aortic endothelial cells. J Cell Sci 110: 547-556

212. Nix DA, Beckerle MC (1997) Nuclear-cytoplasmic shuttling of the focal contact protein, zyxin: a potential me- chanism for communication between sites of cell adhesion and the nucleus. J Cell Biol 138: 1139-1147

213. Fay FS (1995) Calcium sparks in vascular smooth muslce: relaxation regulators. Science 270: 588-589

214. Gordienko DV, Bolton TB, Cannell MB (1998) Variability in spontaneous subcellular calcium release in guineapig ileum smooth muscle cells. J Physiol (Lond) 707-720

215. Laporte R, Laher I (1997) Sarcoplasmic reticulum-sarcolemma interactions and vascular smooth muscle tone. $\mathrm{J}$ Vasc Res 34: 325-343

216. Mironneau J, Arnaudeau S, Macrez-Lepretre N, Boittin FX (1996) $\mathrm{Ca}^{2+}$ sparks and $\mathrm{Ca}^{2+}$ waves activate different $\mathrm{Ca}^{2+}$-dependent ion channels in single myocytes from rat portal vein. Cell Calcium 20: 153-160

217. Graier WF, Paltauf DJ, Hill BJ et al. (1998) Submaximal stimulation of porcine endothelial cells causes focal $\mathrm{Ca}^{2+}$ elevation beneath the cell membrane. J Physiol (Lond) 109-125

218. Blenis J (1993) Signal transduction via the MAP kinases: proceed at your own RSK. Proc Natl Acad Sci USA 90: 5889-5892

219. Fisher TL, Blenis J (1996) Evidence for two catalytically active kinase domains in pp90rsk. Mol Cell Biol 16: 1212-1219

220. Ghoda L, Lin X, Greene WC (1997) The 90-kDa ribosomal S6 kinase (pp90rsk) phosphorylates the N-terminal regulatory domain of IkappaBalpha and stimulates its degradation in vitro. J Biol Chem 272: 21281-21288

221. Xing J, Ginty DD, Greenberg ME (1996) Coupling of the RAS-MAPK pathway to gene activation by RSK2, a growth factor-regulated CREB kinase. Science 273: 959-963

222. Allen RG, Tresini M (2000) Oxidative stress and gene regulation. Free Radic Biol Med 28: 463-499 